\title{
学会賞受賞講演
}

\section{The Role of Rheology on the Shaping Technology of Ceramic Materials}

\author{
by
}

Kaoru UMEyA

The role of rheology on the shaping technology of ceramic materials has been investigated. It was found that the following classification is adequate to describe the rheological characteristics of relevant systems:

(I) the powder system is described as elastico-plastico-viscous solid,

(II) the slurry system, as elastico-plastico-viscous liquid, and

(III) the mud system, as elastico-plastico-viscous solid and liquid, having intermediate character between plastic solid and plastic liquid.

The extended Ostwald flow pattern was studied over a very wide range of shearing rate, in slurry stage. In order to describe a compaction character in powder stage, relaxation properties were studied. And, in mud stage, de-airing process was analysed on the standpoint of rheological phenomenon.

\section{セラミックス成形工学におけるレオロジーの役割}

\author{
梅屋薰*
}

（原稿受理：1985年 9 月 2 日）

\section{I. 粉体系・泥土系・泥漿系の充填構造}

地球上で粉体を报う時には，暗黙のうちに次に書く 3 種類の制 約を受けていることになっている。すすおち，その 1 は重力場で の取报になっていることであり，その 2 は粉体を报うことはその 充填空隙にある空気も一緒に报うことであり，換言すれば，粉 体・空気系を报らことになってしまうということである。更にそ の 3 として湿度の影響からも逃れることが出来ないということ， もっと進んで言えば，水系の介入をも除外して考学られないとい らことである.

この内, 比較的水分の少ない系を粉体系 (Powder system), 水分の多い系を泥漿系 (Slurry system) と呼んで区別している. 更にその中間の水分（粉体の充填間吵を丁度満たすに足る前後の 量の水分) を含んでいる領域を泥土系 (Mud system) と呼ぶ訳 である。

\footnotetext{
* 東北大学名誉教授
}

I-1. 粉体・空気・水系の充媜構造（理想分散の場合） I-1-1. 非活性粉体系の充填構造

粉体·空気・水系の充塤構造を，横軸を水分量に採って示すと Table 1 の関係が得られる. まず水分の少ない側では, 粉体は重 力場下にあるし, 又㠜集力下にもあるので（後記），互いに点接

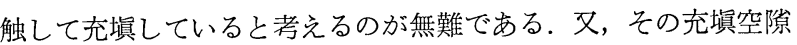
は空気によって満たされている. 表に执いて水分零の所がこれに 相当する充填構造であるが，これに少量の水分が介入して来ると 「理想分散」状態下に执いては (後記), 水の粉体への濡れ特性 と, 水自体の表面張力とによって，水は粉体接点を中心として小 環状体群（ドーナッツ状水環群）に分かれて存在する。この状態 では粉体は（点接触しているので）連続，空気も又充填空隙にあ って立体網を形成していて連続構造となっているが，水は上記し た様に水環群に分かれて存在するので不連続構造となっている.

この状態下で水の量が増して行くと, 增加した水分量は空気を 置換して入るより他に方途がないので, その結果各々の小水環の 容積が增す（それだけ空吵中の空気の立体網容積はやせ細って行 
Table 1 Packing character of powder-air-water system.

\begin{tabular}{|c|c|c|c|c|c|c|c|}
\hline $\begin{array}{l}\text { Particle } \\
\text { (Solid phase) }\end{array}$ & Continuous & Cont. & Cont. & $\begin{array}{l}\text { Dis- } \\
\text { cont. }\end{array}$ & $\begin{array}{l}\text { Dis- } \\
\text { cont. }\end{array}$ & $\begin{array}{l}\text { Dis- } \\
\text { cont. }\end{array}$ & $\begin{array}{l}\text { Dis- } \\
\text { cont. }\end{array}$ \\
\hline $\begin{array}{l}\text { Air } \\
\text { (Gaseous phase) }\end{array}$ & Continuous & Cont. & $\begin{array}{l}\text { Dis- } \\
\text { cont. }\end{array}$ & - & - & - & - \\
\hline $\begin{array}{l}\text { Water hull } \\
\text { (Liquid phase I) }\end{array}$ & \multirow{2}{*}{$\begin{array}{l}\text { Dis- } \\
\text { cont inuous }\end{array}$} & \multirow{2}{*}{ Cont. } & \multirow{2}{*}{ Cont. } & Cont. & Cont. & $\begin{array}{l}\text { Dis- } \\
\text { cont. }\end{array}$ & $\begin{array}{l}\text { Dis- } \\
\text { cont. }\end{array}$ \\
\hline $\begin{array}{l}\text { Free Water } \\
\text { (Liquid phase II) }\end{array}$ & & & & $\begin{array}{l}\text { Dis- } \\
\text { cont. }\end{array}$ & Cont. & Cont. & Cont. \\
\hline Stage & $\begin{array}{c}\text { Pendular S. } \\
\text { P }\end{array}$ & \multicolumn{2}{|c|}{$\begin{array}{l}\text { Funicular } S \text {. } \\
F-1, F-2\end{array}$} & \multicolumn{2}{|c|}{$\begin{array}{l}\text { Capillary S. } \\
\mathrm{C}-1 \mid \mathrm{C}-2\end{array}$} & \multicolumn{2}{|c|}{$\begin{array}{c}\text { Slurry } \mathrm{S} \text {. } \\
\mathrm{S}-1 \mid \mathrm{S}-2\end{array}$} \\
\hline Critical pt. & \multicolumn{5}{|c|}{$c-1$} & $\begin{array}{l}5 \\
\text { quidus } \\
\text { Limit) }\end{array}$ & \\
\hline $\begin{array}{l}\text { Rheological } \\
\text { System }\end{array}$ & \multicolumn{2}{|c|}{ Powder System } & \multicolumn{3}{|c|}{ Mud System } & \multicolumn{2}{|c|}{ Slurry System } \\
\hline $\operatorname{Mix}$ & Dry mix. & \multicolumn{2}{|c|}{$\begin{array}{c}\text { Semi Dry } \\
\text { (or Semi Wet) mix. }\end{array}$} & \multicolumn{2}{|c|}{ Wet mix. } & \multicolumn{2}{|c|}{ slurry mix. } \\
\hline
\end{tabular}

く)ことによってのみ解決される。そして最終的には，それまで 打互いに離れ離れで不連続構造にあった水系が，各々その容積を 增す結果, ある時点では报互いに連絡して連続構造を達成する様 になると考朰れる。

この水系が不連続, 粉体系・空気系は連続の区間を, 充垻構造 上では懸垂域 (Pendular stage, 略してP域) と呼んでいる. 次い で上記した様に水が連続構造化する時点から, 䋐条域 (Funicular stage, 略してF域) に入ることになる。次にF域に扔いて水分の 増すことを考学るのであるが，前（P域）と同じ理由から，水分 が増えること（水環群が容積を増すこと）は, 空気の立体網の内 容積を置換して始めて可能のことであるので, 連続構造化した水 部分（水の立体網）は容積を增すが，反面空気の立体網はそれだ け細って行くことになる.

しかし,な扣この状態下に扔いても暫時, 空気相も連続構造 （立体網）を維持できる区間が存在する。この区間を䋐条域の中 でも特に瀻条-1 域 (Funicular-1 stage 略してF-1域) と呼んで 区別する．また，前に空気の立体網と呼んだものは，粉体の充媜 空隚そのものであったので，その形状は「蛇が卵を吞み込んだ」 様に, 紐の断面積中に太い所と細い所があり得たのであり，この 様な紐が三次元的に集合して立体網を形成していると考えたので あるから，上記した様に空気が徐々に水によって容積置換されて 行くということは, 全体の紐の内径が次第に細まることを意味す るので, 最後は, 蛇が卵を呑んだ様な内径が不揃いである断面を 持つ紐の断面中, 細い所から括られて行って，それまで連続の空 気紐であったものが，今度は独立の空気泡となって閉じ込められ てしまう様になる．先記した様に，F域への入口では水相が独立 性を失って連続化した時であったが，今度は空気が連続性を失っ て独立化する時汇当たる訳である，この間（すなわち空気が独立 性を失って気泡として閉じ込められ，次第にとの容積を減少し て,ついには容積零となるまでの間）はF域の中で特に F-2 域 (Funicular-2 stage, F-2域) と呼ばれている.

表面活性の小さい粉体であれば，充䁲構造はここで終りを告げ，
後は水量が増加すれば一挙に泥漿域(後記)へと移行する.しかし 表面活性の顕著な粉体では，F-2域の後にな招毛管域 (Capillary stage 略してC域) が導入されてくるのであるが，それを理解す るためには, 泥漿域 (Slurry stage 略してS域) の考察の方を先 にして扔く方が便利であるので, 次には $\mathrm{S}$ 域の充填構造に就いて 考えてみたい.

\section{I-1-2. 活性粉体系の充填構造}

表面活性の大なる粉体を水中に入れると，一般には粉体表面に 吸着による液膜（今の場合水膜）構造が形成される。活性粉体系 の充媜構造を考える上では, この吸着液膜構造の寄与を除外して 考えることは出来ない.

繰り返すことになるが，粉体を水に浸すことは，粉体の相と水 の相の外に新しく水膜の相の介入を承認することになるので, 粉 体が単に水に分散するのではなくて，水膜を冠った粉体が自由水 の中に分散していることになるのである．この様にして少量の粉 体を充分に多量の水の中に入れると, 粉体の表面は水膜で覆われ, これが自由液中に分散した形のいわゆる懸濁系を形成する。この 粉体濃度が充分に低い時 (一つの粉体粒子が他の粉体粒子の影響 を受けることなく運動——流動——出来る濃度範囲にある時）を 稀薄泥漿 (あるいは理論泥漿) と呼び, 濃度が高くなって粉体粒 子の運動に水膜の接触の影響が出て来る様になると濃厚泥漿（工 業泥漿）と呼ばれる.

稀薄泥漿では, 分散媒である自由水は連続構造であるが, 粉体 は自由液並びに膜液によって遮蔽されているので不連続構造とな っている. 又, 膜液自体も間で自由液が遮蔽しているので不連続 構造となっている，従って活性粉体の液・固充媜系に扣いては， 粉体・膜液相が不連続, 自由液が連続相となっている状態から出 発する. この状態を泥漿- 2 域 (Slurry-2 stage 略してS -2 域) と呼んでいる.

この状態から水を絞って来ると, 減るのは自由水のみであるの で, 水膜を冠った粉体間に介在する自由水部分は次第にその量が 
減って行き，ついにはつの粉体粒子が運動するに当たり，別の （隣接の）粉体粒子の影響を受けざるを得ない状態となる。すな わち泥漿-1 域 (Slurry-1 stage 略してS-1 域) と呼ばれている 新しい状態が発生する。

更にそれを絞って行くと，ついには膜水の間の自由水の厚さが 零となるので, それまで自由水に遮蔽されて不連続であった膜液 が互いに接触を果たし，連続構造化する様になる。この状態では 分散媒 (自由液) も膜水も連続構造であり, 粉体のみが不連続で ある状態となる。

これから更に水分を絞って行くと，非活性の粉体に和いて F-1， $\mathrm{F}$-2域を論じたときと同じ理由により，自由水が次第に膜水によ って容積置換されて行くことになり（膜水の変形特性も関与す る), ついには自由水が連続性を絶たれ液滴として包み込まれて しまう様になる。ここまでが毛管-2 域 (Capillary-2 stage 略し てC-2 域）と呼ばれる区域となる。

更に脱水すると次第に液滴である自由水はその容積を減少し， ついには容積零となって消隇してしまう。この液滴を含む範囲が 毛管- 1 域 (Capillary-1 stage 略してC-1 域)を構成する。すな わち, ここでは粉体不連続, 膜水連続, 自由水不連続である.

これから更に減水して行くと, 非活性の粉体の項で説明した $\mathrm{F}$ $-2, \mathrm{~F}-1$ 一と横すべりして行き, 最終的にはP域まで脱水が進む 訳である.

従って活性のある粉体では水分の多い側上り $\mathrm{S}-2, \mathrm{~S}-1, \mathrm{C}-2$, $\mathrm{C}-1, \mathrm{~F}-2, \mathrm{~F}-1$ 並びに $\mathrm{P}$ 域へと変化し, その間で自由水・膜水 ・空気並びに粉体粒子の充填性がそれぞれ連続, 不連続とその性 質を变えて行っているのである.

\section{I-1-3. 充填特性間の関連}

この様に，非活性粉体系では，水分の少ない側から

$$
\mathrm{P}, \mathrm{F}-1, \mathrm{~F}-2, \mathrm{~S}
$$

活性粉体系では水分の少ない側から記述して

$$
\mathrm{P}, \mathrm{F}-1, \mathrm{~F}-2, \mathrm{C}-1, \mathrm{C}-2, \mathrm{~S}-1, \mathrm{~S}-2
$$

域が並び, しかも両者の充填システムはF-2の終点の所で接合可 能であることが判明した訳である.

従って結局は粉体・空気・水系の充媜構造には 7 態の充填状態 が本質的に存在していると解釈しなければならない. そして非活 性の粉体ではその中のC域が縮退 (Degeneration) していると言 うことが出来るであろう.

充填状態が 7 態あるのであるから, その間に態間の臨界点が六 つ存在することがうなずかれる。その 6 点を水分の少ない側から $\mathrm{c}-1, \quad \mathrm{c}-2, \quad \mathrm{c}-3, \quad \mathrm{c}-4, \quad \mathrm{c}-5$ 並びに $\mathrm{c}-6$ 臨界点と命名されて いる.

P， F-1 域にある配合 (Mix) が粉体系 (Powder system), F-2，C-1，C-2 域にある配合が泥土系 (Mud system)，そし てS -1，S-2域にある配合が泥漿系(Slurry system) なのであり， かくして懸濁系に猢る三つのレオロジーシステム (Rheology system）が定義されるのである.

\section{I-2. 粉体・空気・水系の充㯖構造（現実分散の場合）}

I-1 に記した内容は凡て理想分散 (Ideal dispersion) を想定 した上で成立することである．現実分散（Real dispersion）にお
いては，次に示す様な諸種の遮蔽効果 (Mask effect) が働くの で，理想分散状態とは大変異なる分散状態が実現する.

その代表的なるのとしては, 粉体域で発生する “造粒効果 (Pelletizing effect)”, 泥土域で発生する “加工硬（軟）化効果 [Work hardening (softening) effect]”, そして泥漿域で遇遭する “捦変硬(軟)化効果 [Thixotropic hardening (softening) effect]” である。これらの遮蔽效果により理想分散状態が強度の影響を受 けるので，それらに就いての内容を把握することにより補正を行 ラ方法の確立が迫られる様になるのである。

\section{I-2-1. 粉体域における遮蔽効果一一造粒現象——に就いて}

多量の粉体の中に数滴の水を落して䚌拌する場合を考えてみよ 5. 分兄た水は粉の一部を捕獲して造粒体 (Pellet)を作るが, 残りの大部分の粉には何らの影響も与えない。この現象は一般に は“ままこ現象”として理解されている.

この様に一部分の粉が粒化し, 更には又一部分の粒が塊化して 行くプロセスは造粒現象並びに造塊現象と呼ばれているが, 粉体 系の現実分散を考光る上で重大な与件の一つになっている。

Fig. 1は横軸沉加える水の量, 緃軸に混練抵抗(Mixing torque) を採って示した関係図である（混練特性図と呼ばれている）。こ れによると, 最初水の添加量の少ない時には混練抵抗は小さいが, 水の添加量と共にその値は増加する $(\mathrm{a}-\mathrm{b})$. しかしこの增加 の傾向はある点 $(b$ 点) で飽和し, それ以降 $(b \rightarrow c)$ は, 混練抵 抗は添加水量と共に減少する. しかし $\mathrm{c}$ 点以降では再び上昇に転 じ, 以後 $\mathrm{d}$ 点に至るまで添加水量と共に増加しているのを知るこ とが出来る， d 点を越すと再び下降法じ $(d \rightarrow e)$ 毛管域 $(C$ 域) へと移って行く.

この混練抵抗の変化は， $\mathrm{a} \rightarrow \mathrm{b}$ 間では上記のままこ現象による 一部の粉体の粒体化によって説明が出来る. b 点に近づくほど粉 は粒によって置換されて行き, 最終的にb点では凡ての粉が粒化 のため使用される結果, 存在するのは粒の及となっている.

$\mathrm{b}$ 点以降では添加水の増量は粉体間の液橋棈成に使用される (Table 1 の緎条-1域に当たる) ので, 粒体間の含有水量が多く なる結果, 表面润滑性に寄与する様になり, 混練抵抗は減少する. しかしあまりに粒体表面の含有水量が多くなると（c 点）〔ここ では粒の変形性も進行している], 表面付着性へと変化する様に なり，今度は塊化への寄与が大となる．すなわち $\mathrm{c} \rightarrow \mathrm{d}$ 間では塊 化した分だけ粒体の減少が発生する，d点で凡ての粒体が塊化を

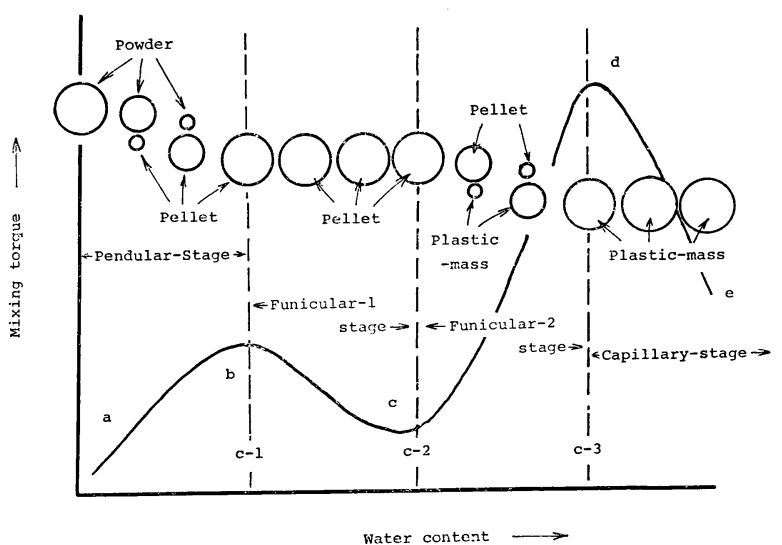

Fig. 1 Pelletizing effect of powder-air-water system. 


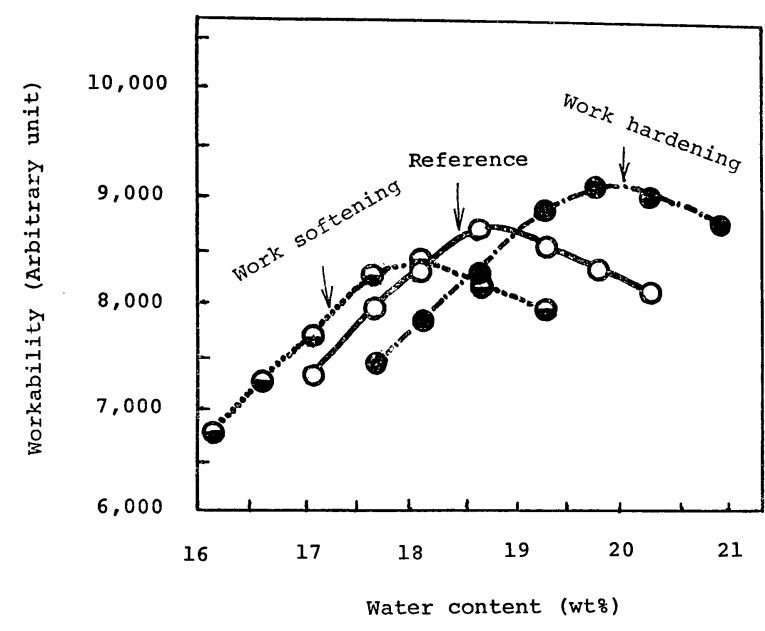

Fig. 2 Work hardening (softening) effect in mud range.

完成するので，それ以降は水分の増加分は塊体の変形性を容易に する様に働くことになる。この関係を図示したものが Fig. 1 で ある。な拈图中には Table 1 の理想分散状態との関連に就いても 示してある.

現実分散では，この様に粉が粒化し，粒が塊化を果たしている ので, 出来た粒を, 又発生した塊を, 発生した時点で押しつぶし て崩壞さすことによって, 出発時の単位粉体にもどしてやる操作 を補足しない限り表 1 の理想分散状態は実現しない。この意味で 造粒・造塊現象が粉体域に打ける遮蔽効果となり，現実分散を理 想分散から分ける原因となるものである。

\section{I-2-2. 泥土域における遮蔽効果——加工硬 (軟) 化現象——に 就て}

泥土のレオロジー特性として, 例えば㨝り特性から降伏值 $\left(y_{0}\right)$ と破壊歪值 $(F)$ を決定し，次いでそれらの積として

$$
(P)_{\text {変形 }}=y_{0} \times F
$$

を決め， $P$ を可塑数と定義して採用することが行われている．泥 土の含有水分を変化させて，各々に就いての可塑数を決定し，水 分（横軸）との関係で整理すると Fig. 2 の実線で示す曲線が得 られる．この曲線を作業特性曲線，山の頂上の位置を最適水分值 と呼んでいる．(1)式は泥土の材料物性を決定する基本式の一つで あるが，これは Thonson によって加工物性との関連が明らかに されるに至って，にわかに重要性を增して来たものである。すな わち，彼は，泥土状物質を取り报う現場に沶いて “こしの強さ”, “ねばりの大きさ”とい5用語が用いられているが，前者は降伏 值によって，後者は破壊に至るまでの最大丕值（破壞歪值と言わ れる）によって関係付けられるものであることを始めて明らかに した.すなわち

$$
\text { 作業性 }(W)=(\text { こしの強さ) } \times \text { (ねばりの大きさ })
$$

を(1)式と対比して用いたのである。

この様な定義による時, 破壞丕值は加工硬(軟)化特性の影響を 顕著に受けるので, その影響を加味して作業特性解析を行うと, 加工硬化の時は Fig. 2 の鎖線が示す曲線の樣になり, 又加工軟 化の時は点線が示す曲線の様になり, 前者の場合は C-1, C-2域 を分ける臨界点 $(c-4$ 点) [「山」の頂上] が多水分側に, 後者の
場合は少水分側に移行する．このことは最適水分值である $\mathrm{c}-4$ 臨 界点（毛管- 1 域と毛管- 2 域の境界点）の移動を意味することに なるので, Table 1 に示した理想分散状態を遮蔽することを意味 する.

従って泥土域に扔いては常にその時働いている加工硬(軟)化の 大きさの数值的把握を試み, その極限值から本来の $\mathrm{c}-4$ 臨界点 を決定することを心掛けねばならない。

\section{I-2-3. 泥漿域における遮蔽効果一一括変硬 (軟) 化現象——に 就いて}

泥獎域に执いても作業性 (Workability) という技術用語が存 在している. 又その内容が，こしの強さとねばりの大きさを含ん でいることも同じである．従って作業性は泥土の項に示した(2)式 で示されている，ただこの場合対応する材料物性による定義であ る(1)式の方が泥土の場合とは異なっている．泥漿の場合，こしの 強さは降伏值 $\left(S_{0}\right)$ で表わされ(1)式の場合と変りはないが，ねば りの大きさに就いては泥土の場合とは異なって, 粘性 $\eta_{a}$ の逆数 である易動性によって表わされている，すなわち，この場合可塑 数 $(P)$ を定義する内容が

$$
(P)_{\text {流動 }}=S_{0} \times 1 / \eta_{\mathrm{a}}
$$

である．従って (作業性)㚆形と(作業性)流動では次元を異にする ものであるが，泥土の現場・泥漿の現場に扔いては各々抜き難い 力を有しているものである.

(作業性) 流動の値も, 粘性従って易動度が揰变の影響を受ける ので，(作業性）変形の場合と類似の 遮蔽効果が発生する．Fig. 3 にその様子が示してある.すなわち，捶変軟化すれば c-6 臨界 点が少水分側に，捶変硬化すれば多水分側に移行する．このこと はS - 1 域と S-2 域の境界の移動を意味するので, Table 1 に示 した理想分散を遮蔽するものであることが判明する。

この場合も前節の場合と同じ様に，捶変性の数值的な把握から 捶変の働かない極限值への外挿を試みる以外飞補正の方法がない。

\section{I-2-4. その他の遮蔽効果}

上述の三種類の遮蔽効果は最も顕著な代表例であるが，この外

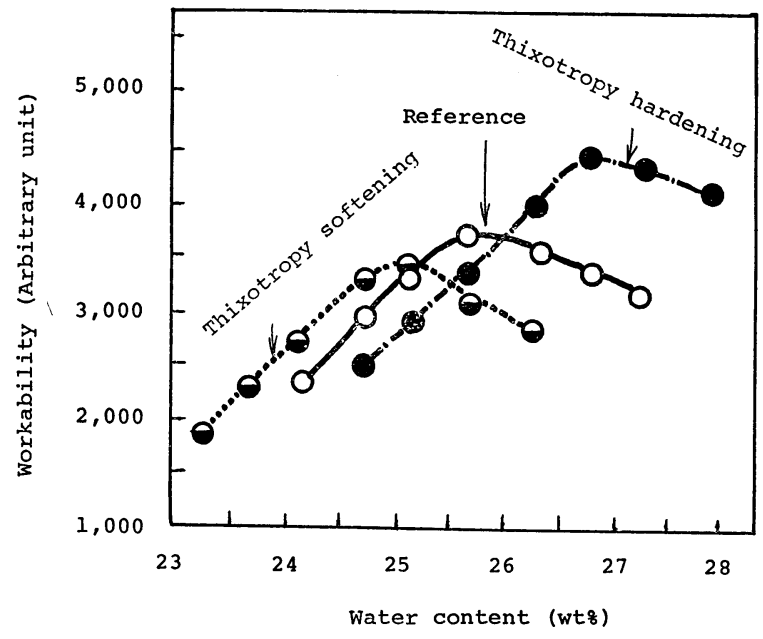

Fig. 3 Thixotropic hardening (softening) effect in mud range. 
にももらろ几遮蔽内容を発揮する物性も二, 三考兄られている. その一つはレオペキシー硬化による戱蔽であり，も5一つは構造 ダイラタンシー（後記）による遮蔽であろう。しかしこれらに就 いては物性值としての解明がようやく緒に着いたばかりの時点で あり, 加工物性との間の関連を論ずるまでにはなっていないと思 われるので, ここでは省略して扔きたい。

以上で粉体・空気・水系 (一般化して粉体 ·気体 · 液体系とし ても類似の取报ができる）の充填構造に怙ける基礎知識を得るこ とが出来たと思われるので, 次章からは, これを基礎として, 粉 体系・泥土系並びに泥漿系のレオロジー特性の究明に当たりたい と思 5 .

\section{II. 泥漿系のレオロジー特性}

\section{II-1. 泥漿系のフローパターン}

泥漿系のレオロジー特性は, 一口に言えば粘塑弾性的液体とし て記述される。すなわち，本質的には流体（粘性体として）とし て扱い得るものであるが，その奥には塑性の項も弾性の項も含ま れていると解釈しなければならないのである。

泥漿系の流動特性は拡張 Ostwald 流動として記述できる (Fig. 4).すなわち流動パターン中には, 三つのニュートン流部分（I Newton, II Newton, III Newton, あるいは略してIN, IIN, IIIN) 領域が存在し, I N より更に低い剪断速度領域に Schwedoff 降伏領域（略してSW）が存在する. XINとIINとの間には疑 塑性 (Pseudo-plastic) 流動である第 1 非 Newton 流動領域（略 してInN, あるいは P.P.) が存在し, 又IINとIIINとの間には レオロジックダイラタンシー (Rheologic dilatancy) 流動である 第 2 非 Newton 領域（略して InN，あるいはR.D.）が存在する。

これに過渡応答部分を加味すると, 擬可塑性流として記述でき る IIInN（第而非 Newton）流と，構造ダイラタンシー(Structural dilatancy）流として記述できる $\mathrm{InN}$ (第 $\mathrm{IV}$ 非 Newton) 流とから なる部分を接合できる (Fig. 5)。換言すれば泥漿物質の流動特

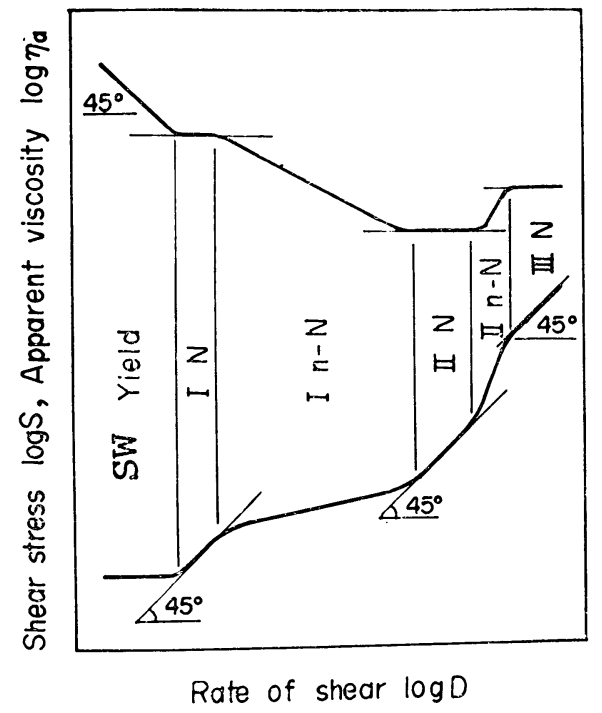

Fig. 4 Dependence of shear stress $(\log S)$ and apparent viscosity $\left(\log \eta_{\mathrm{a}}\right)$ on the rate of shear $(\log D)$ in extended Ostwald flow (equilibrium) pattern.

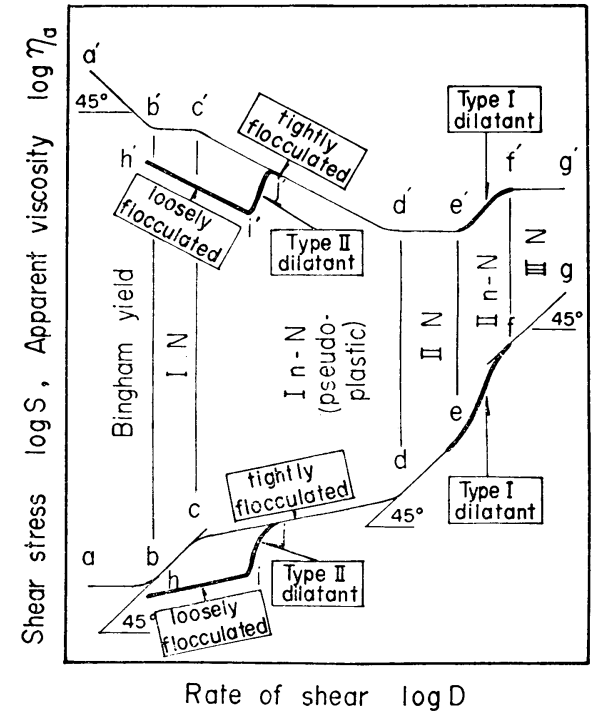

Fig. 5 Dependence of $\log S$ and $\log \eta_{a}$ on $\log D$ in extended Ostwald flow (equilibrium and transit) pattern.

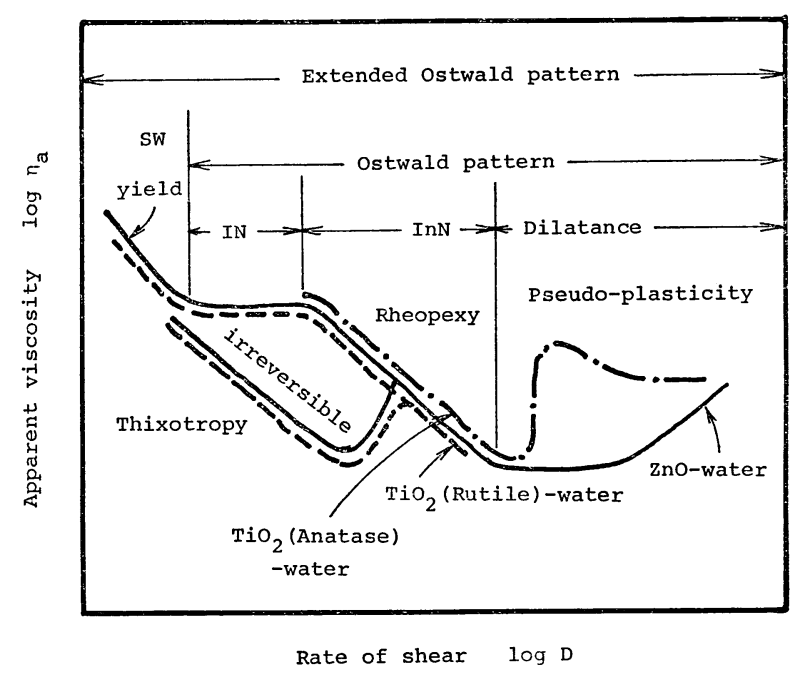

Fig. 6 Extended Ostwald flow pattern obtained from some typical active suspensions.

性としては, 三つの Newton 流動部, 三つの擬可塑性流動部, 二つ のダイラタンシー流動部, それに最下部構造としての Schwedoff 降伏流動が, 大部分は㨁列結合として，一部分は並列結合として 戛結した形でその流動特性の全域を記述することが出来る. Fig. 6 は著者の属していた研究室で, その全域を二, 三の泥漿種を基 にして決定したものである.

あらゆる泥漿は本質的には, この流動形式の全域を内蔵してい るものであると解釈しなければならないが，ただ粉体側の活性・ 液体側の活性 - 両者の相互作用の強弱によって, その一部が縮退 (Degeneration) して観察に乗って来ない場合もあり得るとしな ければならない。かくして IN-InN-IIN のみが表われたもの がOstwald流であり，又これに低速部分としてSW，高速部分と してInN の着いたものが抁張 Ostwald 流動であると解釈する訳 である.この様にして考えられる凡ての拡張流動を Fig. 7 に示 して执いた。 


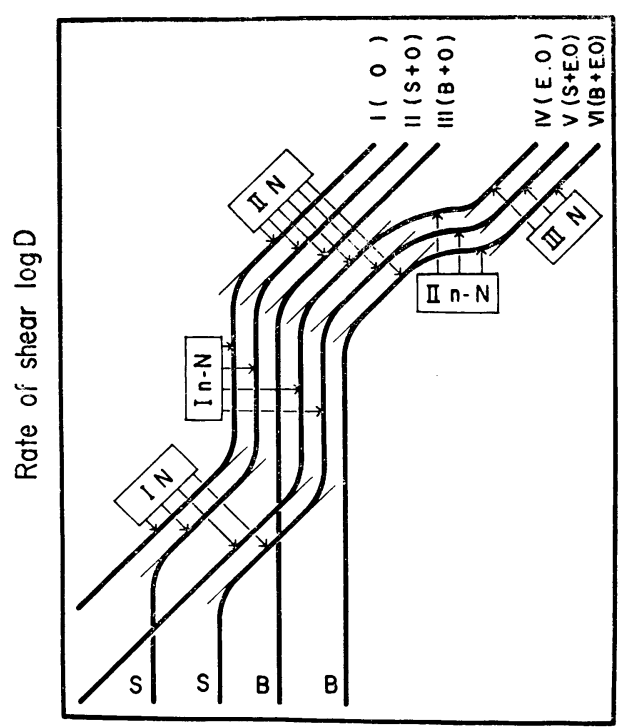

Shear stress logS

Fig. 7 Laminar flow patterns for a wide shearing range. Type I : Ostwald pattern; Type II : Ostwald pattern having Schwedoff yielding property; Type III : Bingham pattern ; Type IV : Extended Ostwald pattern ; Type V : Extended Ostwald pattern having Schwedoff yielding property; Type VI : Extended Ostwald pattern having Bingham yielding property.

\section{II-2. 垂直応力差}

上記の所論に扔いては, 泥漿の機械的特性は粘性ベースとして 披われるとして組み立てたものである。乙かし，懸濁液をはじめ 凡ての分散系に扔ける機械的性質は粘性のみの観点から定義を下 すことは妥当でない，必ずその奥に弾性的な成分が隐されている と考えなければならない，換言すると，泥漿系は正確には粘弾性 系として定義し，その中で粘性項の支配が大きく弾性項の支配が 小さいので上記の様な取扱が可能となったまでである.

泥漿系の弾性項に関わる内容としては, 垂直応力差 $\left(S_{11}-S_{22}\right)$ に就いて考察するのが常道であろ 5 。垂直応力差の測定法として は，(1) PGB 法（毛管流動に打ける管内圧力降下曲線より求める 法. 最初 Philippoff, Gaskins, Bagley により求められたので, 通常 PGB 法と呼ばれる)，(2)ジェット法 (Metzner らによって与 えられた解析法. ジェット噴流の解析值として得られる) の二と 扣りが常用されている．この両測定法による結果を示したものが Fig. 8 である. この結果を見ると $\left(S_{11}-S_{22}\right)_{\mathrm{PGB}}$ の值は $\left(S_{11}-S_{22}\right)$ Jet の值より約 1 オーダー大き目に出ている. この差は今後泥漿 系の流動特性を解釈する上で, その内部構造（後記）との関連を 解积するに当たり，大変重要な拠点となり得ることであるが，残 念ながら現今ではこれに就いての解明は未完成である.

しかし Fig. 8 より，とにかく泥漿系が剪断流れ場に置かれた 場合，必ず垂直応力差が働いていることが判明するので，泥槳系 の流動特性が本質的には粘弾性特性として記述されるべきである とする根拠が明確となった訳である. 又図から想定される様に, この垂直応力差は泥漿濃度と共に大となっているので, 稀薄泥漿 では粘性体としての取扱が許されるとしても濃厚泥漿になればな るほど弾性の寄与をも等閑視出来なくなることを示していると見 なければならない，かくして濃度が高くなり泥土域に入れば，も

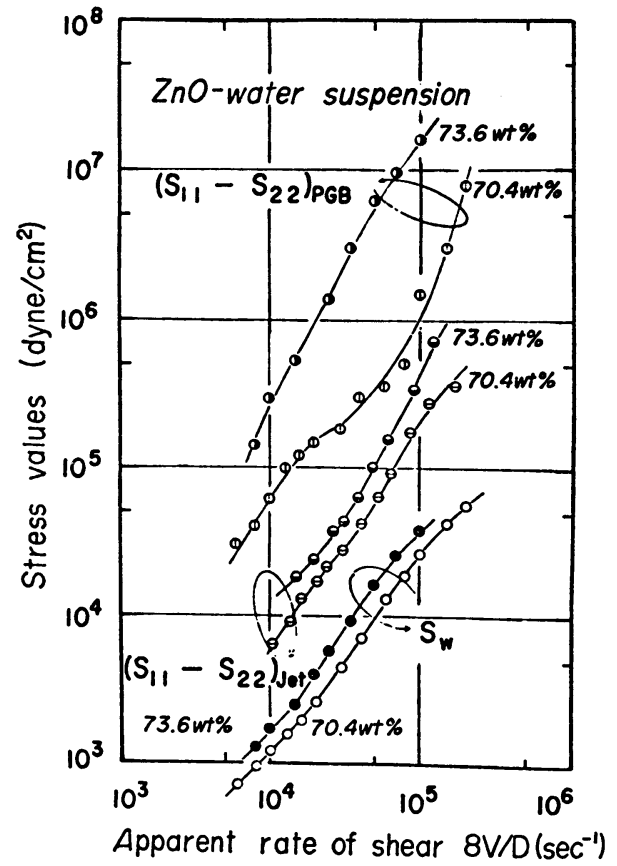

Fig. 8 Dependence of (1) shearing stress $\left(S_{\mathrm{w}}\right)$ and (2) normal stress difference $S_{11}-S_{22}$ evaluated with PGB and Jet methods on the apparent rate of shear $(8 \mathrm{~V} / \mathrm{D})$.

はやその系は粘弾性系としての及記述が可能となるものであり，粘 性系類似の取扱いが不可能となることを示している.

\section{II-3. 流動における微細構造}

分散系の中に一個の分散質を採り上げ，それに別のもう一つの 分散質が無限遠の距離から近接して来る場合を想定し, ポテンシ ヤル曲線を計算すると Fig. 9 の関係が得られる。すなわち，始 めの粒子表面には吸引力として London-van der Waals 力が働き, 又反発力として静電反発力が働く（両作用とも図中に計算式が入 れてある，いずれも著名な式であるので詳細に就いての説明は省 略する). 今, 泥漿として $\mathrm{TiO}_{2} \cdot$ 水系 $50 \mathrm{wt} \%$ 濃度, $\mathrm{Na}_{4} \mathrm{P}_{2} \mathrm{O}_{7} \cdot 10$ $\mathrm{H}_{2} \mathrm{O}$ 解膆系を例飞採って, この吸引力と反発力とを計算したもの が Fig. 9 の(b)図である。 パラメーターとしては上記の解膠剤濃 度 $\left(\mathrm{mg} / \mathrm{g} \mathrm{TiO}_{2}\right)$ を採ってある.いずれの曲線に扎いても，ポテン シャル曲線は, 粒子表面の近傍に扣いて深い第 1 の井戸 (Primary minimum）を持ち, 次いで粒子表面を離れるに際してポテンシ ヤル值は高くなり，次いで一つの山（バリヤー）を越した後再び 低下の傾向をたどり, やがては第 2 の井戸(Secondary minimum) を経て後, 再び上䒜に变じ, その後は平衡值にまで漸近するプロ フィルとなっている. かかるポテンシャル特性から, 二重凝集構 造 (double flocculation structure) の根拠が明らかにされている (Fig. 10)。すなわち，第1の井戸に落ち込んで強固な凝集構造 となったもの (tightly flocculated into primary minimum) が何 個か（図では $6 \sim 7$ 個）集って，それらが一次凝集体 (primary flocculated group）を形成し，次いでそれらの一次凝集体間では， 第 2 の井戸に落ち込んだ軟弱な凝集構造 (loosely flocculated into secondary minimum) である二次凝集体 (secondary flocculated group）を形成すると考えるのである，この一次凝集構造の単位 

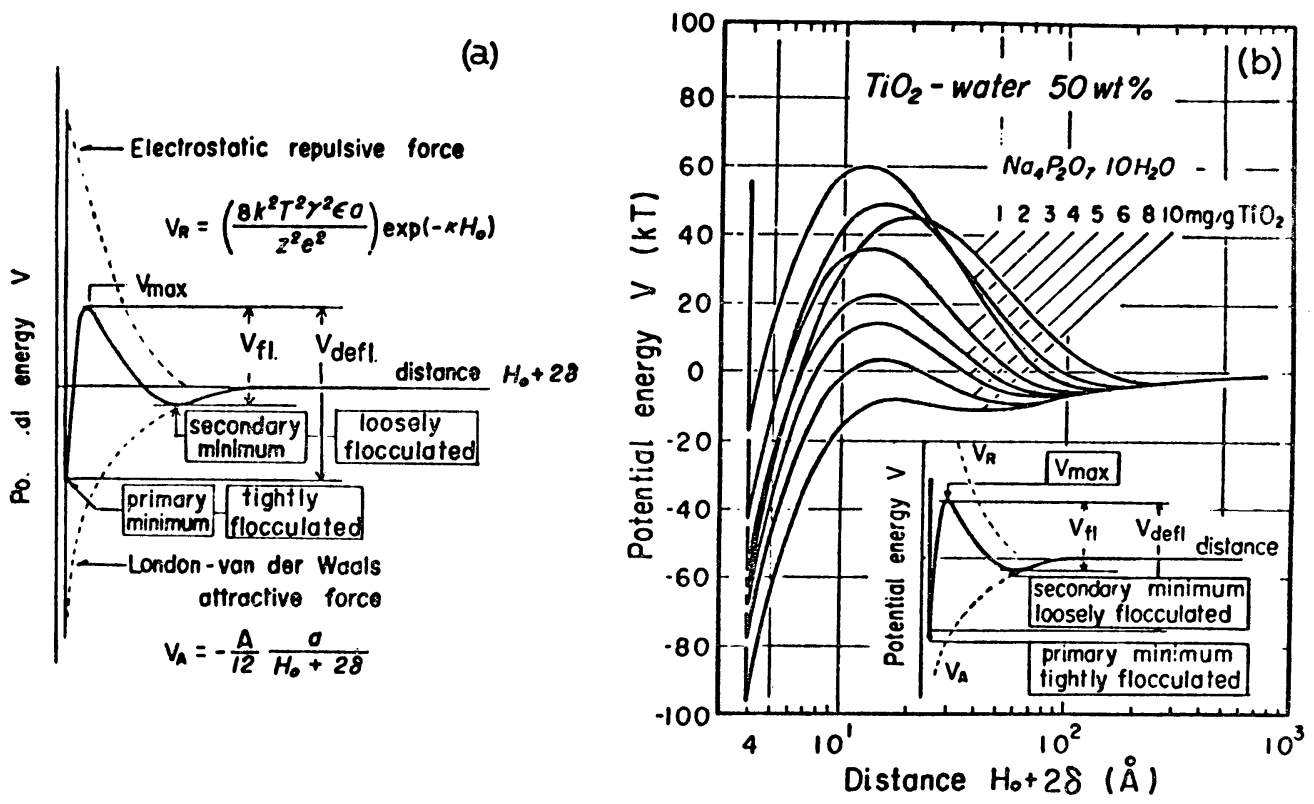

Fig. 9 (a) Schematic representation of the potential energy curve as a function of the distance between two particles. (b) Potential energy curves calculated for $\mathrm{TiO}_{2}$-water $50 \%$ suspensions stabilized with various amounts of $\mathrm{Na}_{4} \mathrm{P}_{2} \mathrm{O}_{7} \cdot \mathrm{H}_{2} \mathrm{O}$.

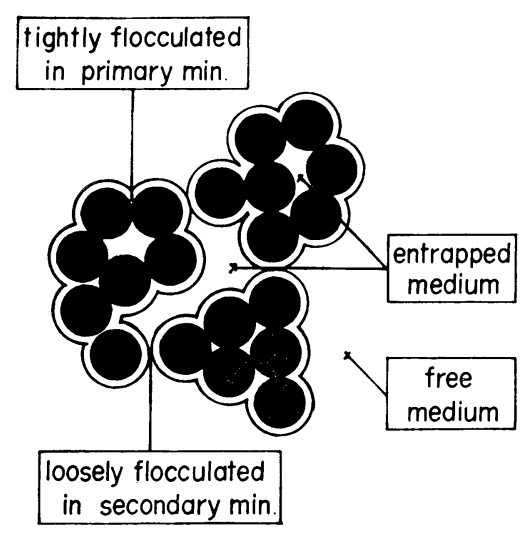

Fig. 10 Schematic illustration of loosely and tightly flocculated structure.

（図では 6〜 7個）と二次凝集構造の数（無限大となった時が Gel 構造）により，凝集構造の内容が決をると考兄られるのである. 又, 外力が㗢いた場合, まず弱い二次凝集構造の所から破断して 行き, 運動単位が小さくなり, 次いで外力が大きくなると, 今度 は一次凝集構造の所も切れて, 更に運動単位が小さくなるという ふうに考えるのである. かくして Gel 構造から次第に運動単位の 小さい流れへと変化して行き，最後には単粒子分散（Sol）とな って, 流れ構造を変えて行くものであると考兄られるのである.

この一次 ·二次凝集構造の仮定を用いることにより, 先記した 拡張Ostwald流動の流動パターンに就いて, その微細構造の解明 を行ならことが出来る (Fig. 11). 寸なわち，この図ではゲルは $m$ 個の単位粒子よりなる一次凝集体と仮定し，この一次凝集体が $n$ 個集って二次凝集体を構筑すると考元る. この二次凝集体に参 画する数が無限大 $(n=\infty)$ であれば，それが巨大分子を意味す るいわゆる Gel 構造となるとするのである，これを外力の働く場
飞置くと，まず軟弱な凝集構造部位（ $n$ で表わされている結合部 位）から切れて行き，より小さい流動単位となる。しかし，この 様にして二次凝集が破壊して行き, 終りに二次凝集に関して単体 化 $(n=1)$ した後で,な扬剪断力が大となると, 今度は $m$ 側すな わち一次凝集側が破壊して行くことになり流動単位がより小さく なるのである.

Fig. 11 では $m=12, n=\infty$ (図中和の点) の構造が, 剪断場に 置かれるとさ，むず $n=\infty$ の值の方から段々に切断されて行き ( $\mathrm{b}^{\prime}$ 点まで), これが降伏現象 (Schwedoff 降伏)を表わす微細 構造であると解釈する。 $\mathrm{b}^{\prime}$ 点より $\mathrm{c}^{\prime}$ 点をで（ＩN域）では，n が小さくなった結果（例えば 4 前後の值にまで短小化した場合), 今度は一時的に準安定化域が発生してよいと考えるのである〔四 面体構造による準安定化の棈想 (Fig. 11 の挿入図)]. 従ってしば らくの間 $\left(\mathrm{b}^{\prime}-\mathrm{c}^{\prime}\right.$ 間) は流動単位に変化が表われないと考兄られ， それ故洦掛け粘性一定で，IN域はかくして発生すると考兄る のである.

しかし， $\mathrm{c}^{\prime}$ 点に到達するとこの準安定構造ももはや維持できな くなり(維持出来なくなる位にまで外力が増加する), 再び $n$ の值 は $4 \rightarrow 3 \rightarrow 2 \rightarrow 1$ とい5ふ5に微細化する ( $\mathrm{j}^{\prime}$ 点での状態). Fig. 10からわかる样に, 一次二次複合凝箱体に执いては, 一次凝集構

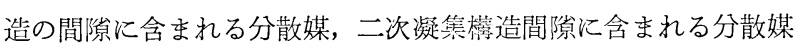
等が考兄られるので, 凝集構造が破壞し, 流動単位が小さくなる

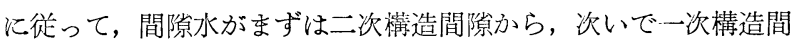
隚から分散媒中に吐き出されて行くので, それと共に泥漿濃度は 稀薄になる．これが粘性低下の原因を構成していると考えるので ある。

次で応力が上昇して行く場合を考えると, 今度は一次凝集体が 切断を受けることになり，すなわち $m=12$ ( $\mathrm{j}^{\prime}$ 点まで）であった ものが， $m=6$ となり更に $m=4$ ( $\mathrm{d}^{\prime}$ 点) となるとい5ふうに微細 化が進行して行く. しかし， $m=4$ に至ると先記した $\mathrm{b}^{\prime}-\mathrm{c}^{\prime}$ 間で 


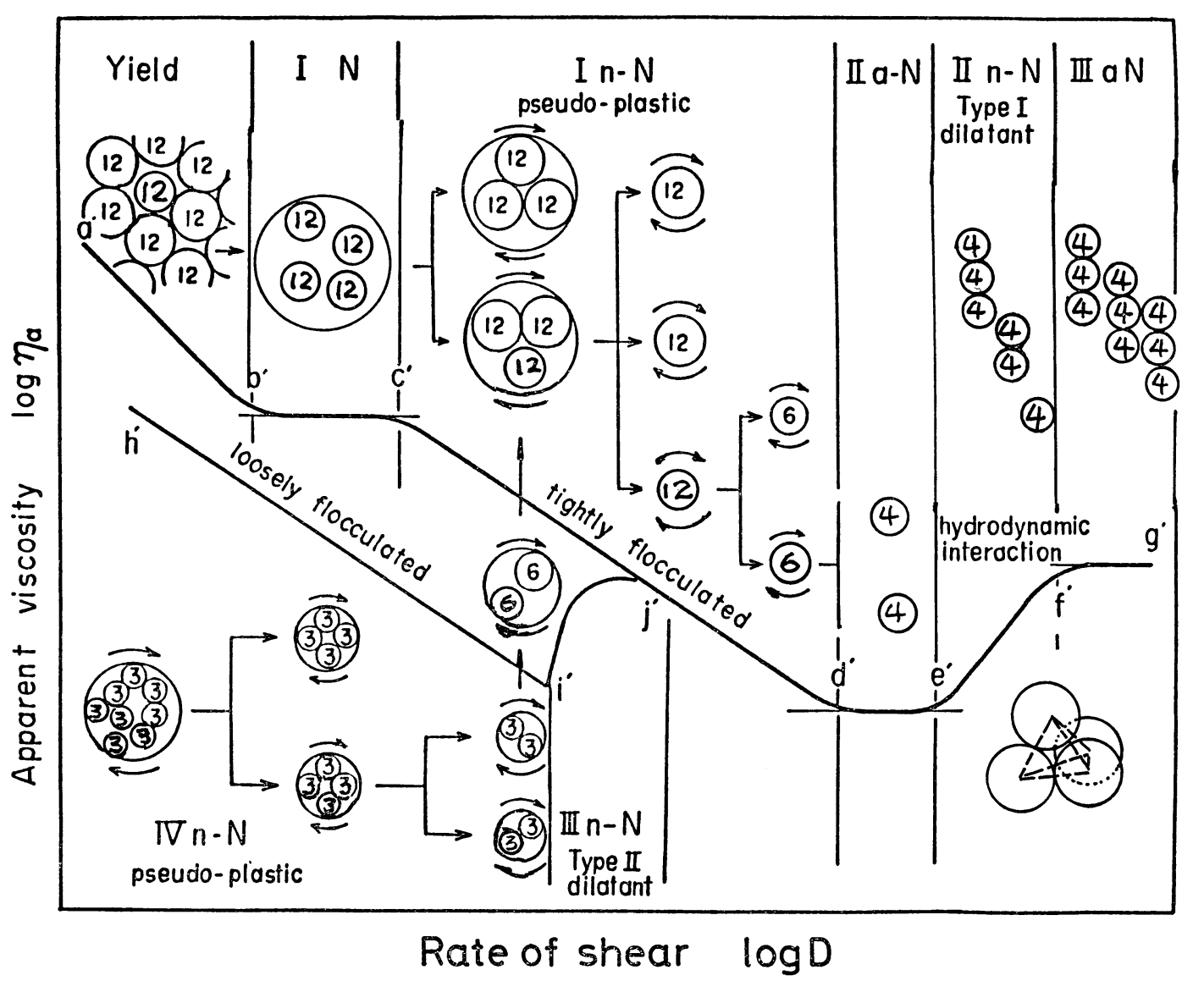

Fig. 11 Flocculation structure in extended Ostwald flow pattern.

考えたことと同じょうなことが発生し，今度は一次凝集構造中で 準安定化が進行すると見られるので, d'よりしばらくの間 $\left(\mathrm{d}^{\prime}-\right.$ $\mathrm{e}^{\prime}$ ) では粘性流動単位としての変化は表われないで斉む（粘性一 定).

更に応力が上升すると, 流線方向への配向が起こる様になり, 流動単位はかえって増大寸る（流動方向に流線に沿って配列し， ダイマー, トライマーの樣な連鎖鹤造を取る方が，エネルギー的 に優先される様になる). $\mathrm{e}^{\prime}$ 一 $\mathrm{f}^{\prime}$ の区間がそれに相当する。几かし この作用もある平衡状態 $\left(m=3, f^{\prime}\right.$ 点) で飽和し, それから後暫 時 $m=3$ の值が保たれる結果, 流動単位が三たび揃うことになる のでIIIN区間が発生することになるのである.

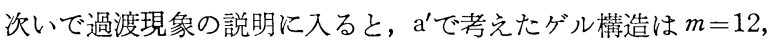
$n=\infty$ であったが, 出発物質としてのゲルは, その調製方法の如 何により別の構造をる採り得ると考兄る方が自然であるう。今, かくして考穴られる異なった構造として，例えば $m=3, n=\infty$ ( $\mathrm{h}^{\prime}$ 点) のゲルから出発して同じことを考劣るとすれば, 剪断速 度と共に $\mathrm{a}^{\prime} \rightarrow \mathrm{b}^{\prime} \rightarrow \mathrm{c}^{\prime} \rightarrow \mathrm{j}^{\prime}$ に起こったことが， $\mathrm{h}^{\prime} \rightarrow \mathrm{i}^{\prime}$ の間に起きると 考えてよいであろ 5 ．異なることは $n$ の值が小さいため，途中で $m$ と $n$ の交換により準安定化という内容が表われると考学られる 点のみであろう $\left(\mathrm{i}^{\prime} \rightarrow \mathrm{j}^{\prime}\right)$. これは外力が構造構成に使われる区間 であるので, 系の粘性は外力の消費分に相当するだけ, 粘性の向 上に資すると考学るのが妥当であるう。こう考光ることにより， $a^{\prime} \rightarrow b^{\prime} \rightarrow c^{\prime} \rightarrow j^{\prime} \rightarrow d^{\prime} \rightarrow e^{\prime} \rightarrow f^{\prime} \rightarrow g^{\prime}$ の間が可逆であるが， $h^{\prime} \rightarrow i^{\prime} \rightarrow j^{\prime}$ を 通って $\mathrm{d}^{\prime} \rightarrow \mathrm{e}^{\prime} \rightarrow \mathrm{f}^{\prime} \rightarrow \mathrm{g}^{\prime}$ に至ったものは, 復路に括いて $\mathrm{j}^{\prime} \rightarrow \mathrm{i}^{\prime}$ に行
かず $\mathrm{j}^{\prime} \rightarrow \mathrm{c}^{\prime} \rightarrow \mathrm{b}^{\prime} \rightarrow \mathrm{a}^{\prime}$ と通り得ること（すなわち非可逆応答するこ と）を納得出来るであろう.かくして拡張 Ostwald 流動パター ンの全域を粒子ベースの構造単位から解釈することが出来るので ある.

\section{III. 粉体系のレオロジー}

粉体系を律するレオロジー的性質は塑性である。一般には塑性 的性質を解明するに当たっては緩和特性 (Relaxation character) と匍匐特性 (Creep character) によることが賢明とされているが， 粉体域の中水分の少ない側（P域）は緩和特性から，水分の多い 側（F-1域）は匍甸特性から, その塑性（降伏性と塑性流動性） の決定が行なわれているのが常態である.ここでは前者の場合に 就いてのみ述べて执きたい。

III-1. 圧密プロセスにおけるレオロジー特性

容器中に粉体系 (P域) を入れて (Fig. 12), 压密するとき (いわゆる圧縮プロセスに招いて), 圧密経路を Fig. 13 の挿入図 のごとくすると, 压密特性として通常 Fig. 13 の本図に見られる 様なループ曲線が得られる. 図には温度によるレオロジー的性質 が既に決定済みであるポリスチレン粉体を $25^{\circ} \mathrm{C}$ (弹性体として挙 動), $60^{\circ} \mathrm{C}, 77^{\circ} \mathrm{C}, 90^{\circ} \mathrm{C}$ 並びに $95^{\circ} \mathrm{C}$ (高温になる注ど粘性体とし ての挙動が支配的となる）の各温度に拈いて型中王密（すなわち 圧縮）プロセスに掛けた場合に就いての圧密特性が, 加圧並びに 除圧の両経路に扔いて示してある. 
(a)

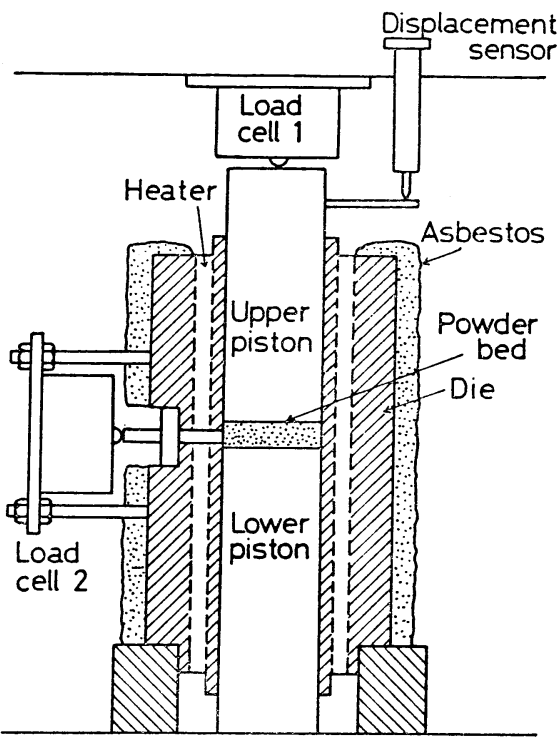

(b)

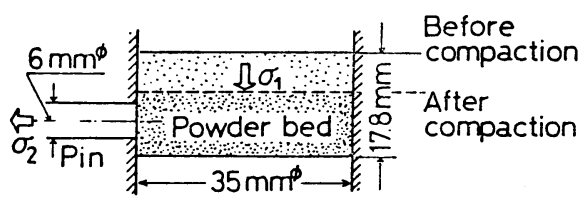

Fig. 12 (a) Apparatus for compaction test; (b) The powder bed.

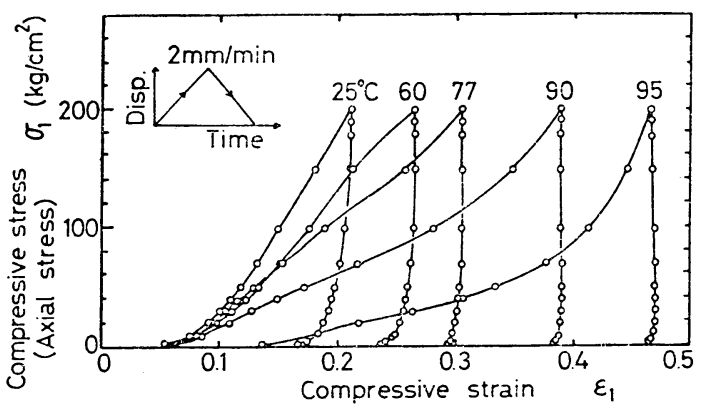

Fig. 13 The stress $\left(\sigma_{1}\right)$-strain $\left(\varepsilon_{1}\right)$ diagrams during loading and unloading (compaction).

圧密経路に拈いて復路（除圧過程）に沶いては (Fig. 14 参照)， 圧密応力 $\sigma_{\mathrm{a}}$ に招いて圧密歪 $\varepsilon_{\mathrm{a}}$ の一部 $\varepsilon_{\mathrm{r}}$ が回復されるが, 残り

$$
\varepsilon_{\mathrm{l}}=\varepsilon_{\mathrm{a}}-\varepsilon_{\mathrm{r}}
$$

は回復しないで残留歪として残る。換言すれば，压密過程は歪に 関して非可逆である. 又，この性質は高温に至る汪ど，一定圧密 応力 $\sigma_{\mathrm{a}}$ 下では压密霆 $\varepsilon_{\mathrm{a}}$ の值は大となるが，その $\varepsilon_{\mathrm{a}}$ の中で回復 分 $\varepsilon_{\mathrm{r}}$ は小さくなり，非回復分 $\varepsilon_{\mathrm{i}}$ の值は圧倒的に大となっている ことが見いだされている．このことでは粉体種がポリスチレンで あり, ポリスチレンでは低温 $\left(25^{\circ} \mathrm{C}\right)$ では弾性的であるが, 高温 になるに従って $\left(60^{\circ} \mathrm{C} \rightarrow 70^{\circ} \mathrm{C} \rightarrow 90^{\circ} \mathrm{C} \rightarrow 95^{\circ} \mathrm{C}\right)$ まず望性の勝った粘 弾性体, 次いで粘性の勝った粘塑弾性体へと徐々に移行している ことが説明出来るからである.（しかし，この項に就いては降伏 值の連続分布という特異なレオロジー的概念の導入も必要とされ ている.)

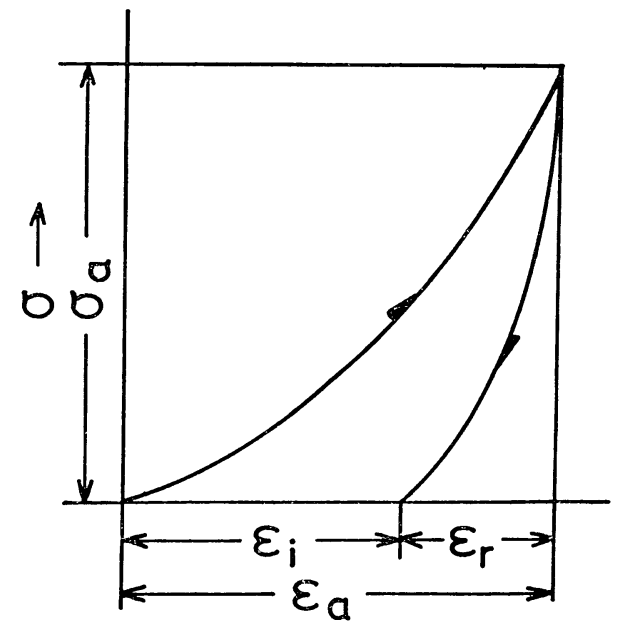

$\varepsilon \rightarrow$

Fig. 14 Hysteresis curve obtained in compaction procedure.

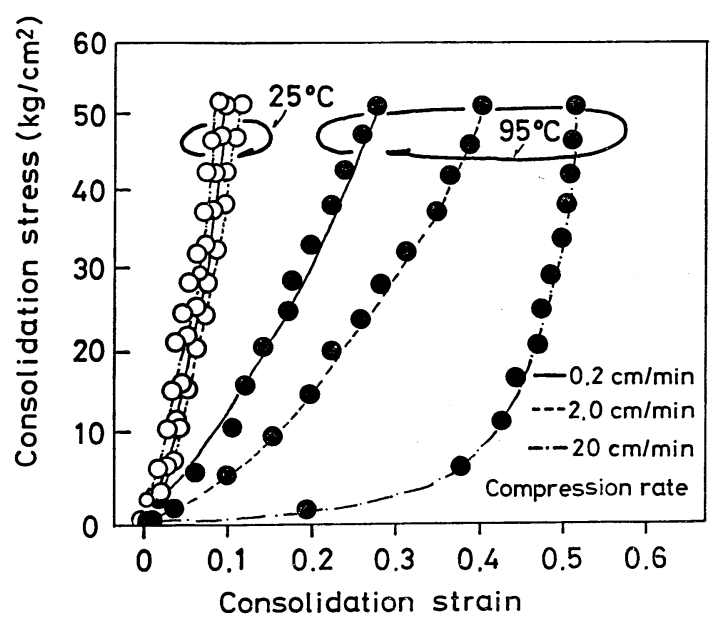

Fig. 15 Compaction rate dependence.

一方, 圧密速度を変化させた場合の応答に就いては Fig. 15 の 結果が得られている。つまり低温 $\left(25^{\circ} \mathrm{C}\right.$, 弾性体として挙動) で は圧密速度の影響を受けないが，高温になるほど塑粘性体として の挙動, すなわち粘性の影響が加わってくるので, 速度の影響を 強く受ける様になって来るのである.

\section{III-2. 圧密プロセスにおける緩和特性}

さて，压密プロセスに拈けるレオロジー的性質を決定するため には, 従来種々の試みがなされているが, 最終的にはFig. 16 に よる方法が推奨されている. すなわち, 同図(a)の上部の挿入図が 示すように, 型 (モールド) 中に括いて圧密偏位 $(d)$ が一定值 $\left(d_{\mathfrak{a}}\right)$ になるまで圧密を進行させ， $d_{\mathrm{a}}$ 值に到達した時点で, その 炡值 $\left(d_{\mathrm{a}}\right)$ を保持することにより, 応力緩和特性を観察するので ある. この場合, 压密忍力の側から見ると, 同㘠(a)の右下插入㘠 が示している様に, 加圧過程に执いて応力 ( $\sigma_{1}$ 第一主応) は増 加するが，緩和過程に入ると，それ以降では典型的な緩和曲線を 描いて減少して行く，従って，かくして得られる圧密偏位 $d_{\mathrm{a}}$ の 值を種々に变えて緩和特性を測定すれば，それらより緩和時間 

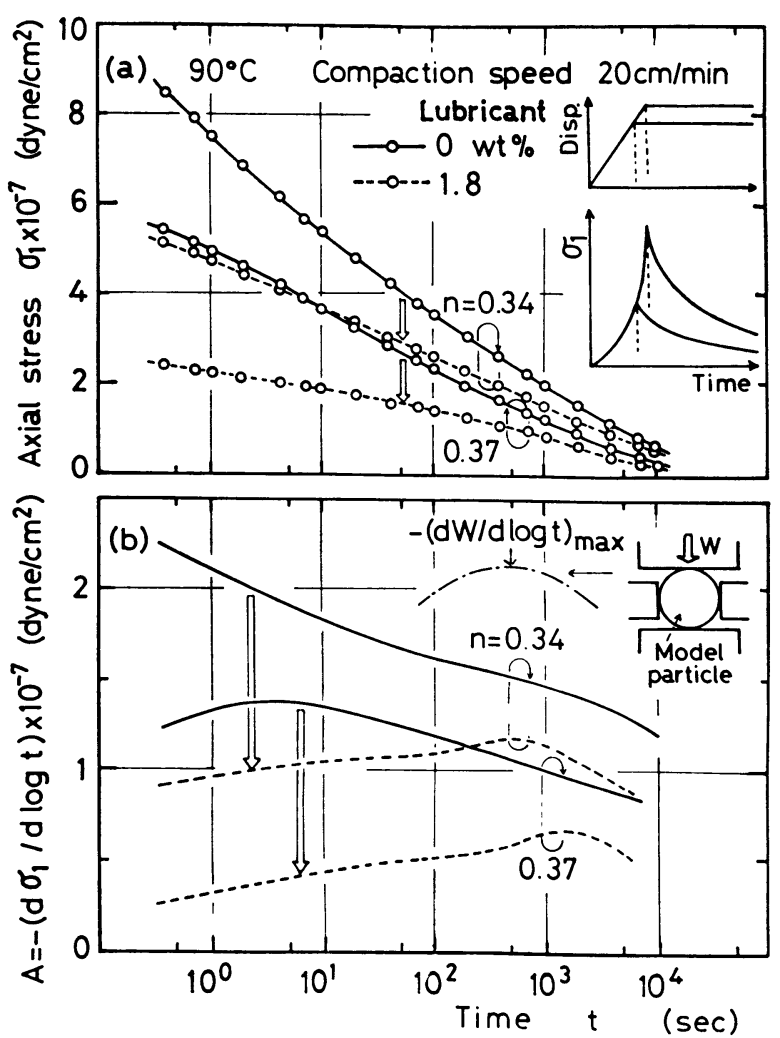

Fig. 16 Relaxation of axial stress (major principal stress) $\sigma_{1}$ under constant void fraction $n$.
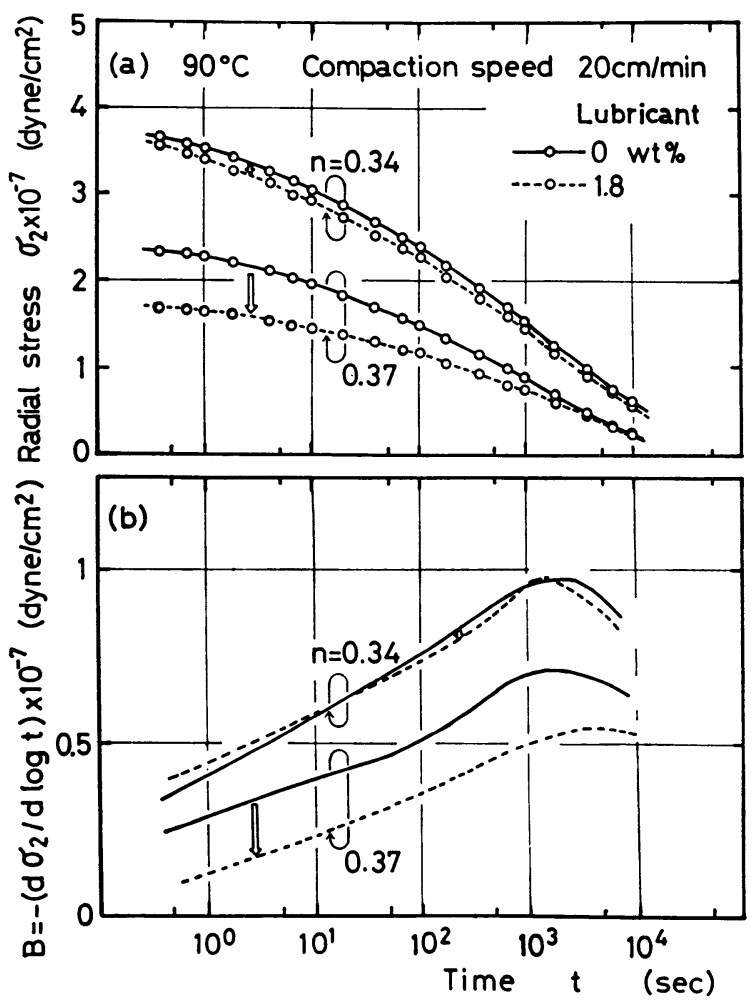

Fig. 17 Relaxation of radial stress (minor principal stress) $\sigma_{2}$ under constant void fraction $n$. $(\lambda=\mathrm{d} \sigma / \mathrm{d} \log t, \lambda$ 時間, $t$ 時間, $\sigma$ 応力) 值が得られる.

Fig. 16 (a), Fig. 17 (a) にかくして得られた第一主応力 $\sigma_{1}$, 第二主応力 $\sigma_{2}$ の緩和特性を，Fig. 16 (b)，Fig. 17 (b) にそれ を対数時間で微分して得られる緩和時間の分布曲線（第一近似に よる指示に相当）が示してある。それぞれ最初の空隙率 $n=0.34$ 並びに0.36, 又型面を潤滑した場合としない場合とに就いても示 してある.

これらの結果では, 粉体の譲り合い機構と推定される短時間側 $\left(10^{0} \sim 10^{1} \mathrm{sec}\right)$ 飞一つの分布の山, 次いで粉体自身の变形機構 によると推定される長時間側 $\left(10^{3} \mathrm{sec}\right)$ 飞別の分布の山の存在が 推定されるが, Fig. 16, Fig. 17 の状態では, この辺のレオロジ 一的な意味付を充分行なえるほど鮮明な測定結果とはなっていな w.

これらの関係をより明確にするには, SMP (Spatial mobilized plane) への投射という作業仮説の適用が推奖されている。すな わち Fig. 18 飞示寸様に, 三主応力 $\sigma_{1}, \sigma_{2}, \sigma_{3}$ 上り決まる座標 面 $\left[\sqrt{\sigma_{1}}, \sqrt{\sigma_{2}}, \sqrt{\sigma_{3}}\right]$ 上で, 純粋圧縮応力 $\sigma_{\mathrm{SMP}}=3 J_{3} / J_{2}$ 並びに純 粋剪断成分 $\tau_{\mathrm{SMP}}=\sqrt{J_{1} J_{2} J_{3}-9 J_{3}^{2} / J_{2}}$ (ただし $J_{1}=\sigma_{1}+\sigma_{2}+\sigma_{3}$, $J_{2}=\sigma_{1} \sigma_{2}+\sigma_{2} \sigma_{3}+\sigma_{3} \sigma_{1}, J_{3}=\sigma_{1} \sigma_{2} \sigma_{3}$ とする. 又, 今の場合 $\sigma_{2}=\sigma_{3}$ である）を分けて計算するのである（Fig. 18).

Fig. 19 (a), Fig. 20 (a) 飞第一主応力 $\sigma_{1}$, 第二主応力 $\left(\sigma_{2}\right.$ $\left.=\sigma_{3}\right)$ より求めた $\sigma_{\mathrm{SMP}}$ 並びに $\tau_{\mathrm{SMP}}$ の緩和の形状を, 同じく Fig. 19 (b), Fig. 20 (b) 飞 $\sigma_{\mathrm{SMP}}$ 並びに $\tau_{\mathrm{SMP}}$ より求めた分布 曲線が示してある（この場合も第一近似法による指示となってい る). かくして得られた関係から純粋圧縮成分では $t=10^{3} \mathrm{sec} に$, 純粋剪断成分では $t=10^{0} \mathrm{sec}$ 以下の部分に，その分布関数の山が 存在するのを観察できるので, 前者は粉体の変形特性, 後者はそ の譲り合い特性からの寄与として理解することが出来る.

しかし，ここに注意を要することは，上記の取报は圧密層の径 がその厚さに較べて充分大きい時 $(d / l>7)$ 飞执いてのみ成立す る関係であり, 普通理論圧密層と呼ばれているすのに就いての解 析例であった．実際の圧密では，この様な偏平層の圧密ももちろ ん取り报われているが（ＩＣをはじめとするエレクトロセラミッ クスである基盤等がこれに入る)，多くの場合においては $d / l の$ 比は 7 よりさくなっているので，この場合に就いての取报は， 前記の内容のことを単に平均值的な取报をしかも不正確に行なっ ているにしか過ぎないことにしている，それではこの様な厚層の 型内圧密 (圧縮) プロセスに拈いては, 取报は如何にあるべきか

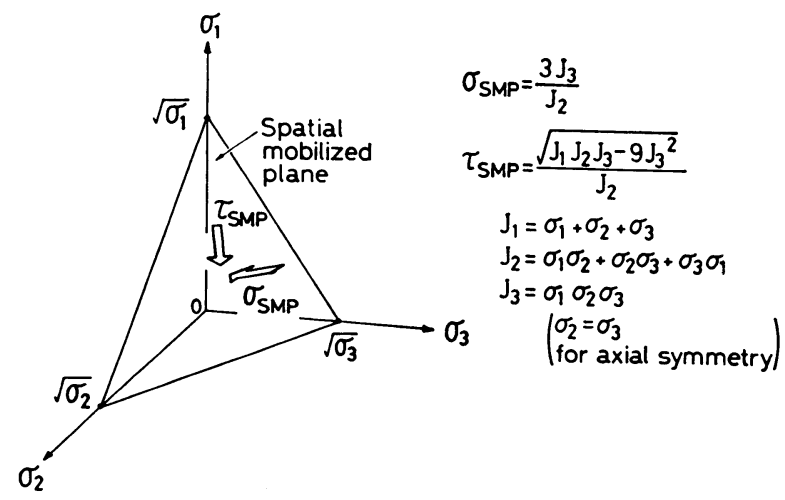

Fig. 18 The spatial mobilized plane (SMP). 


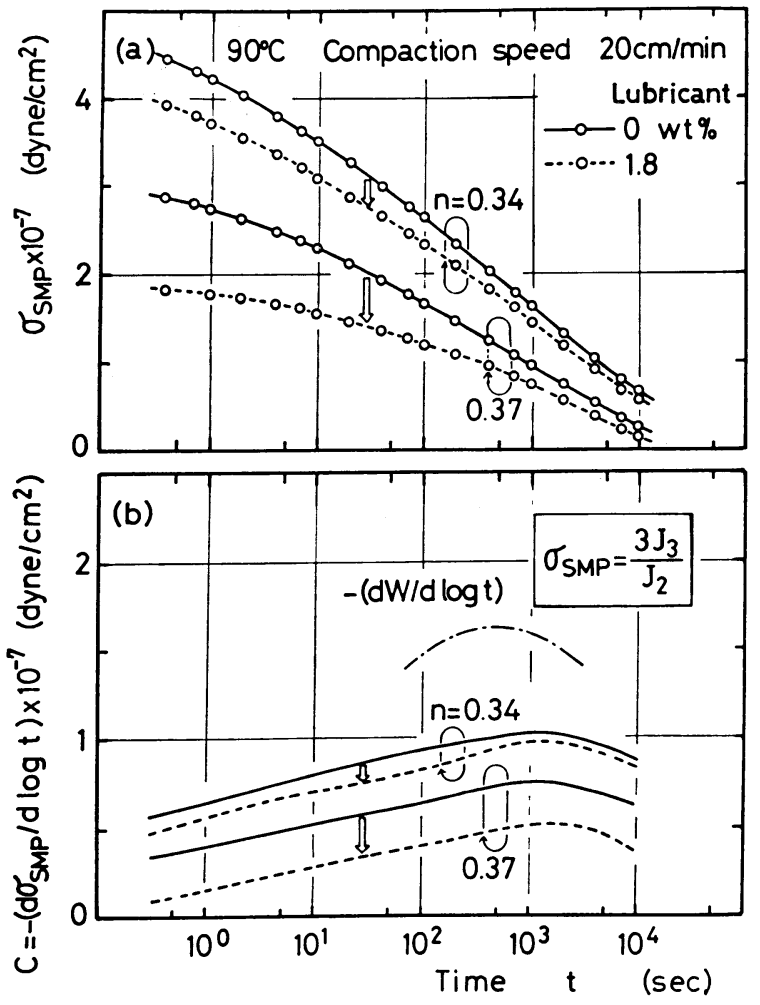

Fig. 19 Relaxation of normal stress on SMP, $\sigma_{\text {SMP }}$, under constant void fraction $n$.
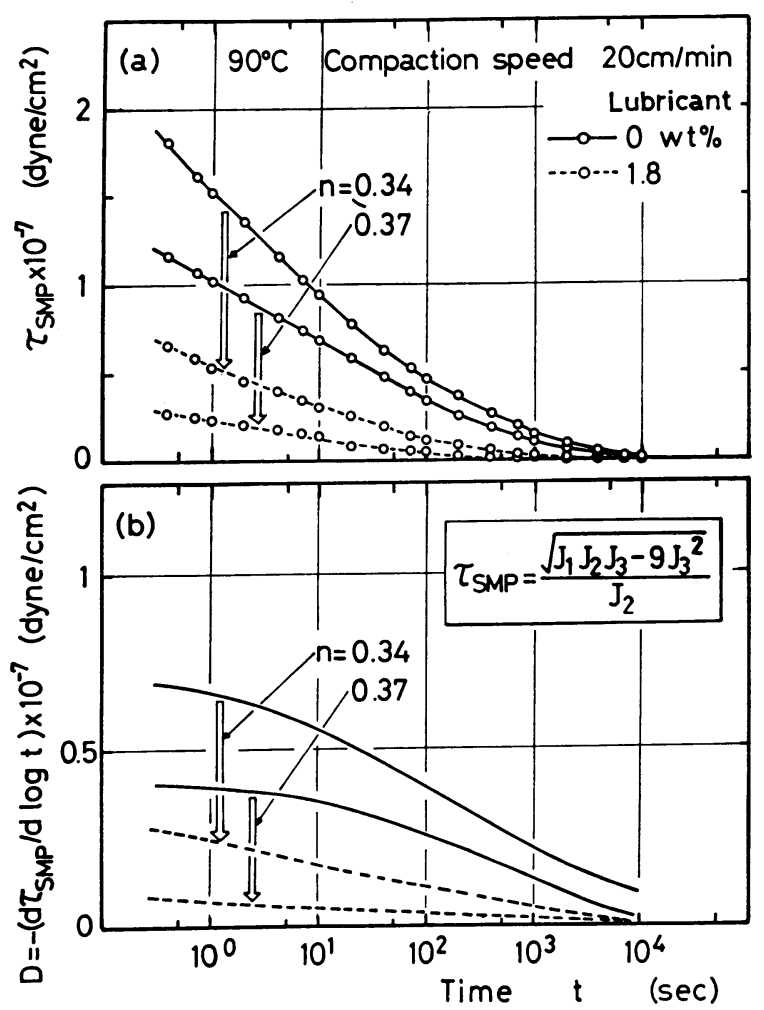

Fig. 20 Relaxation of shear stress on SMP, $\tau_{\mathrm{SMP}}$, under constant void fraction $n$.
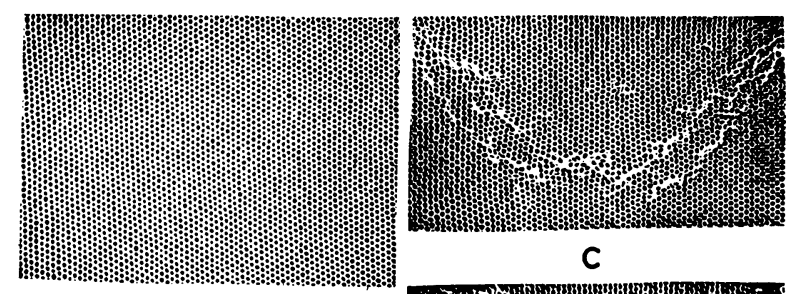

C

a

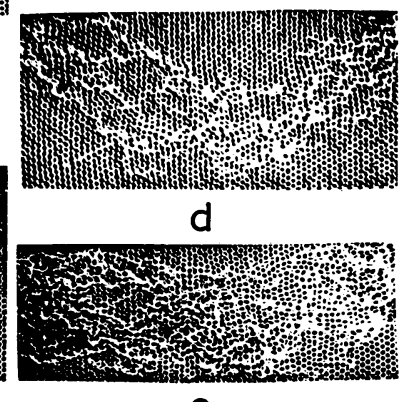

b

e

Fig. 21 Stress distribution observed in two-dimensional model consolidation.

に就いて次節以下に説明を試みて行きたい。

\section{III-3．圧密プロセスにおける微細構造}

型中で圧密層の厚さが厚くなった場合の圧密過程を, モデル圧 密 (二次元観察結果として) で示して括く.

\section{III-3-1． 応力分布の観察}

三次元圧密では圧密プロセス中の微細構造の変化を可視化し難 いので, 二次元圧密に置換して行なった観察結果をFig. 21 に示 した，応力分布を検知するためには，応力のかかる部位に扎いて 変形圧壊などが起こりやすい二次元粉体材料を選ぶと有利である. ここではビニールパイプ（径 $4 \mathrm{~mm} \phi$, 長さ $5 \mathrm{~cm}$ ) 〔ソーダ水を领 む時のストローパイプを切断したもの）の堆積体を二次元の圧縮 枠内に作ったものを, スターティングマテリアルとして, これを

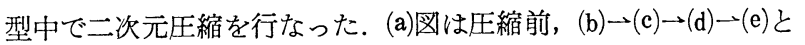
行くに従って压縮変形は大となっている.

先記した様にビニールパイプは応力のかかった場所に扣いて変 形し, 且つその応力が大きくなると圧壊するので, その変化の模 様から，そこにかかっている応力の大きさを検知することが出来 る. (b)図では上面両肩部（三次元に直すと上面円周部）に拈いて 発生応力が大で, 反面, 上面中央部では発生応力は小さい. 下面 ではこれとは逆に中央部で大きく, 周辺部で小さい，更に変位の 進行した(c)四ではこの関係が一そう顕著になっているのを知るこ とが出来る. 又, 第一の圧壊層から数粒子層離れた所で次の（第 二の）圧壊が進行しているのを知ることが出来る．これは金属材 料などに扣いてバイルビー滑り層の形成される機構と類似の現象 (一種の加工硬化) である.すなわち, 粒子充填系の滑り特性は 加工硬化の現象であると理解できる. 更に変形が進むと ( d 図), この関係は更虂骨に表われて招り, 又最終段階（e因）に扣い てさえも, 上面中央部, 下面両端部に締りの悪い部分が残されて いることが明確に観察される. 


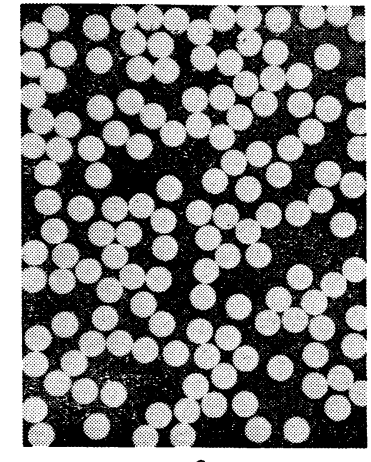

a

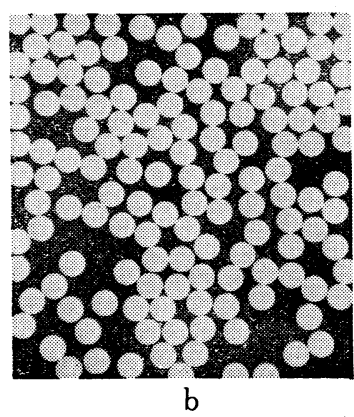

Fig. 22 Strain distribution observed in two-dimensional model consolidation.

\section{III-3-2. 歪分布の観察}

今度は歪の分布を観察してみよう。使用した二次元粉体試料は アクリロニトリル又はポリウレタン樹脂（いずれも光弾性感度の 大きい材料) よりなる棒状試料 $(10 \mathrm{~mm} \phi, 50 \mathrm{mmL})$ で，棒の筒 表面にワセリンを塗付して付着性を与えたものである。これを Fig. 22 (a) 亿示寸様に二次元に粗充填し，これを出発物状態とし て圧密する．(b)は少し圧密変位の進んだ状態を示すが，上面で両 端，下面で中央部より圧密化が進行しているのがわかる。(c)図は 更に圧密変位の進んだ状態が示されているが，(b)図で説明した内 容が更に顕著になっていることを観察出来る。(d)(e)いずれも変位 の進行と共に上記した内容の進行が，微細構造としても5かがわ れることを示している．この傾向は圧密の最終段階まで残り，結 果的には成形体中に粗密の分布を創り出するのであることを理解 することが出来る。

\section{III-3-3. 応力值, 歪值の計算例}

Fig. 21 並びに Fig. 22 の応力分布並びに歪分布は, 元来一方 から他方を互いに計算値として割り出すことが可能のものである. 今その一例として後者の例, すなわち歪分布測定值より応力分布 を計算する場合に就いて紹介しておきたい。

Fig. 23 は Fig. 22 と同じ様にして求めた, 三次元型中圧密プ ロセスより求められた成形体中の偏位分布である。すなわち, 型 中にあらかじめFig. 24 の様にして標線を施して扣き，それを压 密成形したときの歪分布を示するのである。これより Table 2 の (a)(b)の計算式を使用することにより，压縮応力 $\sigma_{\mathrm{x}}, \sigma_{\mathrm{y}}$ を求めた ものが Fig. 25, 剪断応力 $\tau_{\mathrm{xy}}$ を求めたものが Fig. 26 である.

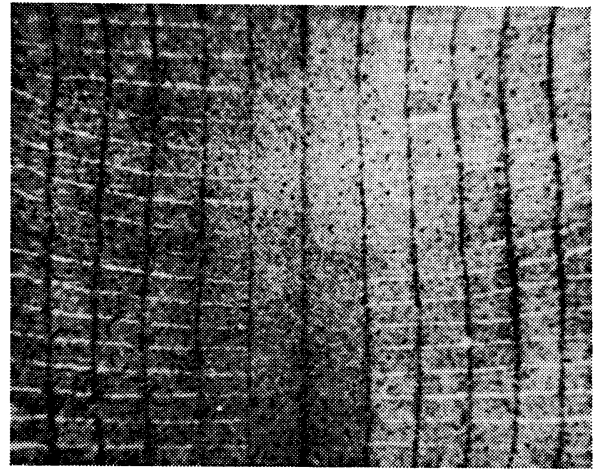

Fig. 23 Three dimensional consolidation (one direction compaction).

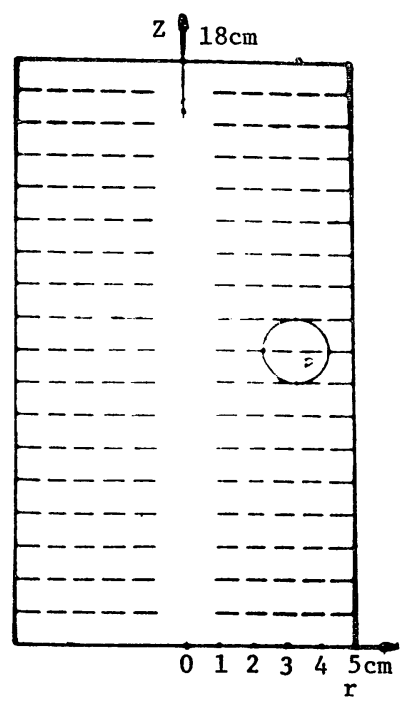

Fig. 24 Packing structure before consolidation (three dimensional model test).

Table 2 Calculation formula of stress from strain.

$$
\begin{aligned}
& \sigma_{\mathrm{x}}=K_{0}(1-K)\left[\left(\varepsilon_{1}{ }^{n}-\varepsilon_{2}{ }^{n}\right) l_{1}{ }^{2}+K \varepsilon_{1}{ }^{n}+(1+K) \varepsilon_{2}{ }^{n}\right] \\
& \sigma_{\mathrm{y}}=K_{0}(1-K)\left[\left(\varepsilon_{1}{ }^{n}-\varepsilon_{2}{ }^{n}\right)\left(1-l_{1}{ }^{2}\right)-K \varepsilon_{1}{ }^{n}+(1+K) \varepsilon_{2}{ }^{n}\right] \\
& \tau_{\mathrm{xy}}= \pm(1-K)\left(\varepsilon_{1}{ }^{n}-3_{2}{ }^{n}\right) l_{1} \sqrt{1-l_{1}{ }^{2}} \\
& \sigma_{\mathrm{x}}, \sigma_{\mathrm{y}}: \text { Normal stresses } \\
& \tau_{\mathrm{xy}} \quad: \text { Shear stress } \\
& \sigma_{1}, \sigma_{2} \text { : Principal stresses } \\
& \varepsilon_{1}, \varepsilon_{2} \quad \text { : Principal strains } \\
& l_{1} \quad \text { : Direction cosine } \\
& K_{0}, n \quad \text { : Constants in eq. } \sigma_{1}=K_{0} \varepsilon_{1}{ }^{n} \\
& K \quad \text { : Rankine's coefficient } \\
& K=\frac{\sigma_{3}}{\sigma_{1}}=\frac{1-\sin \phi}{1+\sin \phi}+\frac{C \cot \phi}{\sigma_{1}}\left(\frac{1-\sin \phi}{1+\sin \phi}-1\right) \\
& \phi \quad \text { : Angle of internal friction } \\
& C \quad \text { : Cohesive strength }
\end{aligned}
$$

画図に沶いて縱軸 $\mathrm{A}$ は成形体中心軸，Dは筒面軸， B 並びにC それらの中間位置にある標線である. 又 line a は最上面, line e は最下面, line b, c, d はその中間の面を上面に近い側から順序 

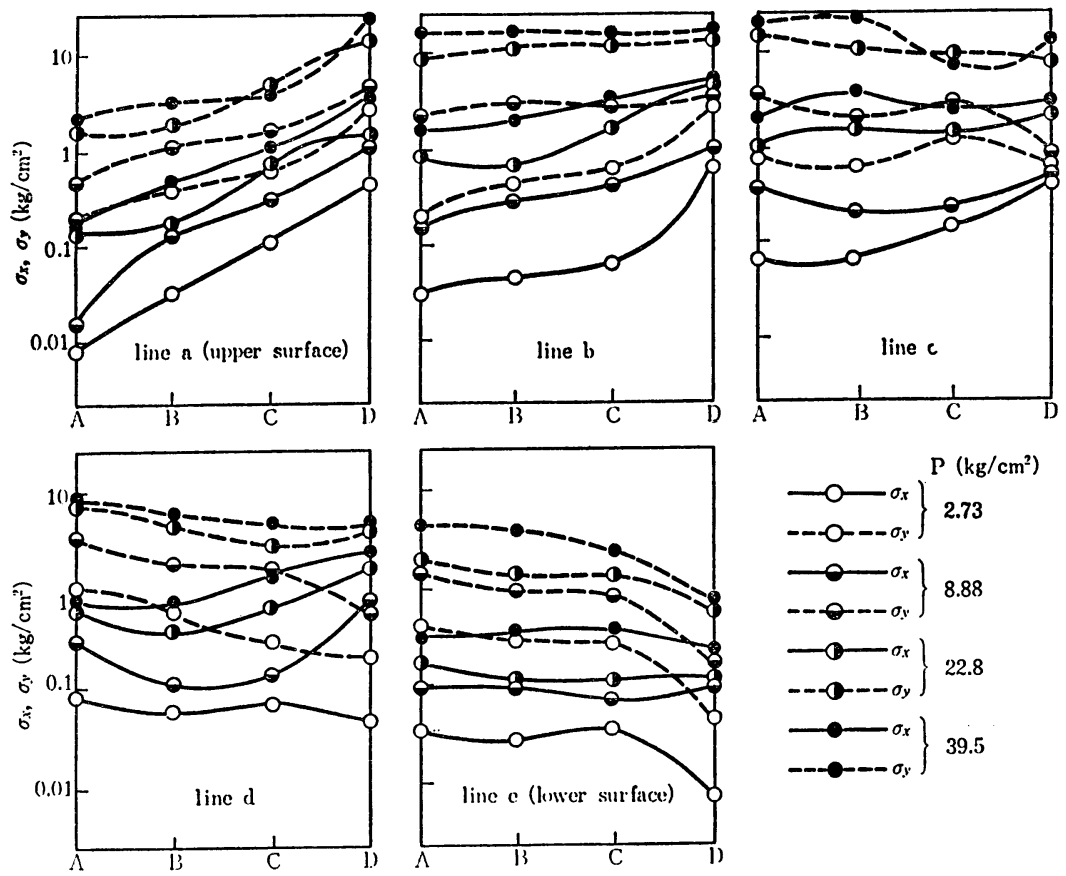

Fig. 25 Calculated values of normal stresses $\sigma_{\mathrm{x}}$ and $\sigma_{\mathrm{y}}$.
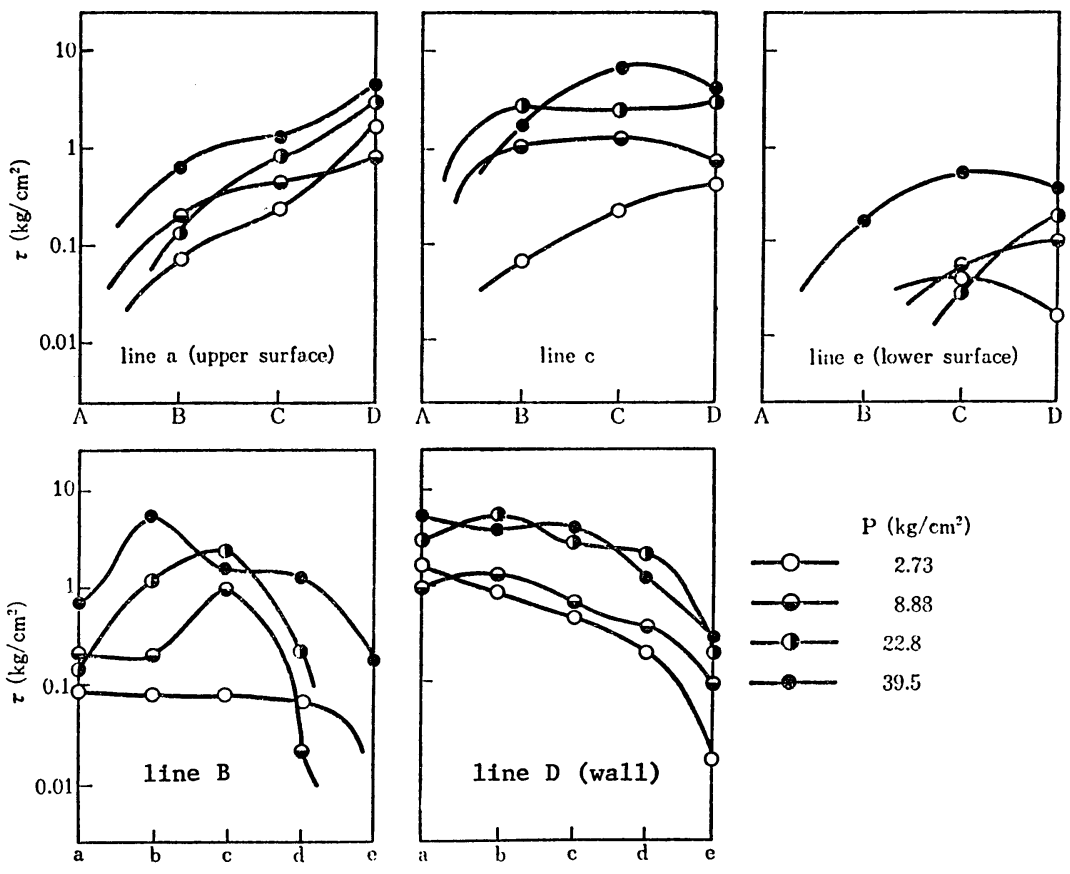

Fig. 26 Calculated values of shearing stress $\tau$.

に示したものである (Fig. 27)。これらの四から，上面 ( $\mathrm{a}$ - a ) では周辺部 (D-D) がよく縮り，下面 (e-e) では中心部 (A -A）働く応力 $\left(\sigma_{x}, \sigma_{y}\right.$ とも) が大であることが判明する. 更 に上面 $(\mathrm{a}-\mathrm{a})$ では中央部 (A-A), 下面 $(\mathrm{e}-\mathrm{e})$ では周辺部 (D-D) 飞拈いて応力の大きさが小であることをも知ることが 出来る。な抗これらの計算方法を適用することにより, 圧密プロ セスの種々のプログラムに対して, 応力分布の解析, ひいては歪 分布の解析にも当たることが出来る.

\section{III-3-4. 厚手成形体の均質成形}

その結果, 均質成形体を得るためのノウハウとも言うべき内容 の確立が試みられるようになっている。紙面の都合から，それに 就いては結果のみを書いて扰く。

条件 1. 粉体の内部摩擦係数 $\mu_{1}$ の值を小さくすればするほど, 王密成形体中の密度分布は均質となる。

条件 2. 粉体の型面に打ける滑り摩擦係数 $\mu_{\mathrm{s}}$ の值を小さくすれ ばするほど，圧密成形体中の密度分布は均質となる。 


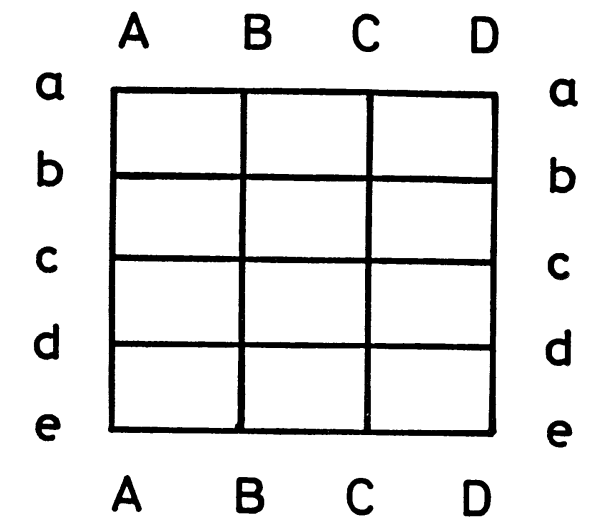

Fig. 27 Calculated locations in Fig. 25 and 26. a : top ; e : bottom ; A : center ; D : side wall.

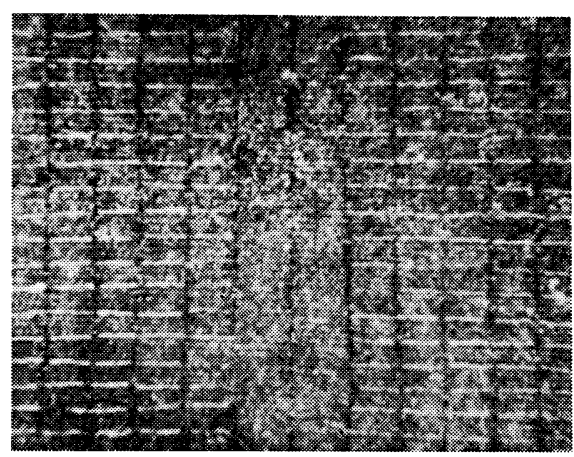

Fig. 28 Packing structure obtained from double mode consolidation.

条件 3. 圧密速度を小さくすればするほど, 圧密成形体中の密度 分布を小さくすることが出来る。

条件 4. 復動システムを採れば均質成形体の取得に貢献出来る.

さて, 条件 4 に記した復動圧密システムに就いて, 少し説明し て持きたい，先記した様に厚物圧密に沏いては，Fig. 24 の様な 充填構造をとるとき，压縮後 Fig. 23 に示寸樣に上面では周辺部， 下面では中央部が高密度となる様な構造体となることが判明して いる．いまこれを上下両方向から圧密すると，中心部で Fig. 23 を上下に重ねた様な構造となり歪分布の改善に資することは出来 ない。

しかし，この場合，上部より約 7 割を締めた後，ある一定時間 $(\Delta t)$ を放置して，その後で今度は下部より残りの 3 割を締める という操作を行なえば Fig. 28 が示す様に少なくとも実験的には 均質成形体を取得することが出来る。この方法は複動圧縮システ ムと呼ばれ，粉体圧密操作の基本原理の一つを形成している.

上記した上部より約 7 割, 下部より残りの約 3 割をとい 5 量比 並びに往復の压密の間に置く時間 $(\Delta t)$ は, それぞれの粉体にと って固有の值であるが，特に $\Delta t$ という特性時間の值が微妙な影 響力を発揮するものであるので，今まで多くの先行研究に执いて， その意味する内容に就いて解明が行なわれた。

しかしかくして決められた $\Delta t$ の物理的内容に就いては, つい 最近に至るまで, その物理的意味付けを行ならには至っていなか った。これが解明されて系の有している緩和時間であることが証
明されるに至ったのはつい最近のことであるが，それを機会に粉 体材料工学あるいは粉体成形工学の飛踓が行なわれることになっ た.

\section{IV. 泥土系のレオロジー}

前節までの所論により, 粉体系は粘塑弾性固体として, 又泥漿 系は粘塑弹性液体として取り扱い得るものであることが判明した. 泥土系は, 先記した栏に水分含有量に捺いて 粉体系と泥漿系と の中間に存在する。すなわち F-2, C-1，C-2域に相当する液分 を含有しているし, 又そのレオロジー特性に就いても, 粘塑弾性 固体と粘塑弾性液体としての举動の両面が表われると考㝋られる. すなわち遅い変形速度に対しては粘塑弾性液体として, 又速い変 形速度に対しては粘塑弾性固体として举動する。この様に泥土系 は粘性流動もするし, 又塑性変形もすることの出来る系であるの で, 粉体系と泥漿系の両方のレオロジー特性を有した系として記 述されるべきものなのである.

\section{IV-1． 真空土練}

泥土系のレオロジー物性として最も有効な解析手段は, 前記 （I-2-2）した作業特性曲線である. Fig. 29 は泥土の各種調製 条件によって変化する作業特性曲線を示したものである. 図中 c 一系統とは，泥土中の粘土（可塑性粉体）含有量依存性，(33，35, $38 ， 40 ， 42 \%$ と変化させてある)，ｇ系統は粉砕時間による変化 (10，20，40，80時間と粉碀時間が変えてある)， a 系統は熟成 による変化（熟成日数 $0 ， 7 ， 28$ 日と变化させてある)， $\mathrm{v}$ 系統 は脱気時の真空度 $(760,510,400,190,150,25,10 \mathrm{mmHg}$ と変 化させてある）による作業特性曲線の变化の模様を追跡してある.

粘土量の增加 (可塑性粉体の添加量の增加), あるいは微粉砕 による調製条件のときには，作業性曲線自体も高い位置に動いて いて作業性の改善が暗示されているが，同時に含有水分值も大と

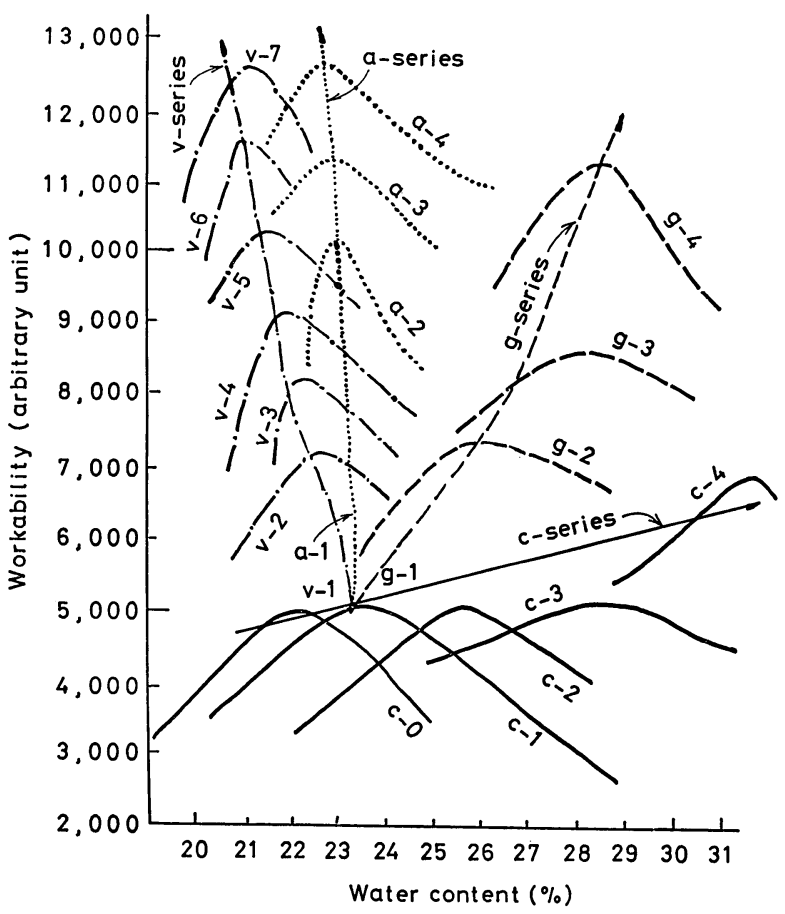

Fig. 29 Workability relation obtained in slurry stage. 
なっている，これに反し，熟成によるときには，含有水分に変化 を来たさず作業性特性のみ改善でさている，セラミックス成形作 業等に执いては（他のプロセスでも大部分そうであるが）, 成形 は処理工程の一部でしかなく, 成形のために使用する水分は, 成 形後の処理（乾燥，焼結）を考学たら，なるべく少ない方が望ま しい，このためセラミックス成形等においては熟成による作業性 の改善が最適とされて来ている．このため極端な場合には一年と か二年とかを単位の熟成も行なわれる様になり, 原料の回転上不 都合を来たす場合も発生した。

これが脱気処理によると，水分值はむしろ少ない側に移動し， しかも作業性の改善を短時間の内に行ならことが出来るので, 泥 土処理技術としては革新的な面を開拓することになった.

この様にして脱気土練の有効性が重要視されるに至ったのであ るが，その理由に就いての解明はそれより遅れて，次に述べる様 な形で展開することになった。

そもそも泥土を調製するには, 乾式調土法と湿式調土法の二種 類の調製法が存在するが，乾式調土法による場合には，F-2域を 通過する際閉じ込められた空気泡の除去が難しく, 又造粒遮蔽効 果（I-2-1）の発生のため, 練り上げた（調製を終えた）泥土中 に水分の不均分が発生することを避けることが出来ず，部分的に 平均水分上り高い所, 平均水分に近い所, 平均水分上り低い所等 の混在した状態（疎原土と呼ぶ）を繰り上げているに過ぎないこ とになっている. 又湿式調土法による時にも, 出発物質である泥 漿を脱水するに当たり，㬵って脱水しても乾燥によって脱水して も，いずれの場合に执いても先に脱水を受ける部分と後で脱水を 受ける部分では, 粉体充埧体の構造, 従って含有水分值の場所に よる偏在が発生する。文泥漿䚓挷時に空気泡の混入が避けられな いし, 更には調土時と処理時の温度布により, いったん含有水分 中に溶解していた気体分が気泡となって排出されることも免れな い. 従って泥土調製条件の如何を問わず，含有水分の部分的偏在， 気泡含有のマイナス要因からは解放されない.

この様な疎原土の水分の平均化並びに気泡の除去を行ならには, 前者に対しては捏和処理, 後者に対しては脱気処理が要求され, 果ては両処理の合体した形である真空土練混練操作の重要性が叫 ばれる様になって来たのである。
(a) Original mud
(b) Cuiting
(c) Separating

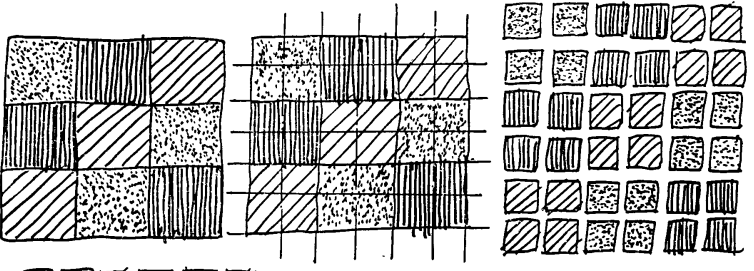

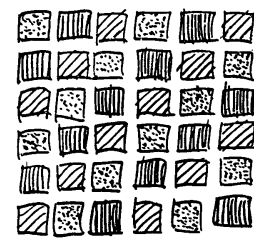

(d) Mixing

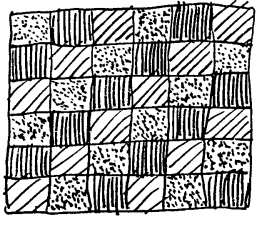

(e) De-airing and

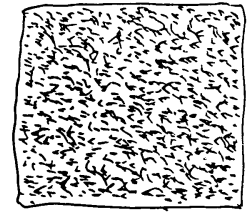

(f) Kneaded-mud
Fig. 30 Structure change during kneading procedure.

今, 調製後の踈原土をFig. 30 (a) に示す様に, 平均より水分 の多い区域を斜線, 平均より水分の少ない区域を縱線, 平均の水 分を含んだ所を点々て示し, この水分偏差を少なくするための混 練操作の内容を説明すると，まず(a)で示した状態の疎原土を，(a) に括沙る水分区域上り狭い幅で切断して行き(b), 次いでこれらを 分離し (c), 後混合(d)する。このとき切片面間に空気が介在された まま一体化するので，空気を内藏気泡として包み込むことになる ので，これの除去のためには真空雾囲気下で混練することが必要 となって来る. 本当の所はその上に圧縮混練と剪断混練の両操作 を加味することにより, 水分の多い所から水の少ない所へ内蔵水 分を拡散させる．この混練により，疎原土中の水分は平均化され， 又脱気もされることになるのである.

真空土練機はこの 6 操作 (切断・分離・混合・圧縮練り・剪断 練り, 脱気) を一機種で可能としたものであるが, Fig. 31 の構 造となっている.すなわち, 前段混練部, 後段混練部と両混練部 を連結する真空脱気室部分とからなっている.

い屯，平均水分に近い水分を含んだ原土部分を点々，平均より 多い水分を含んだ原土部分を斜線, 平均より少ない水分を含んだ 原土部分を縱線で表わし，それら混合物を投入口より投入する。

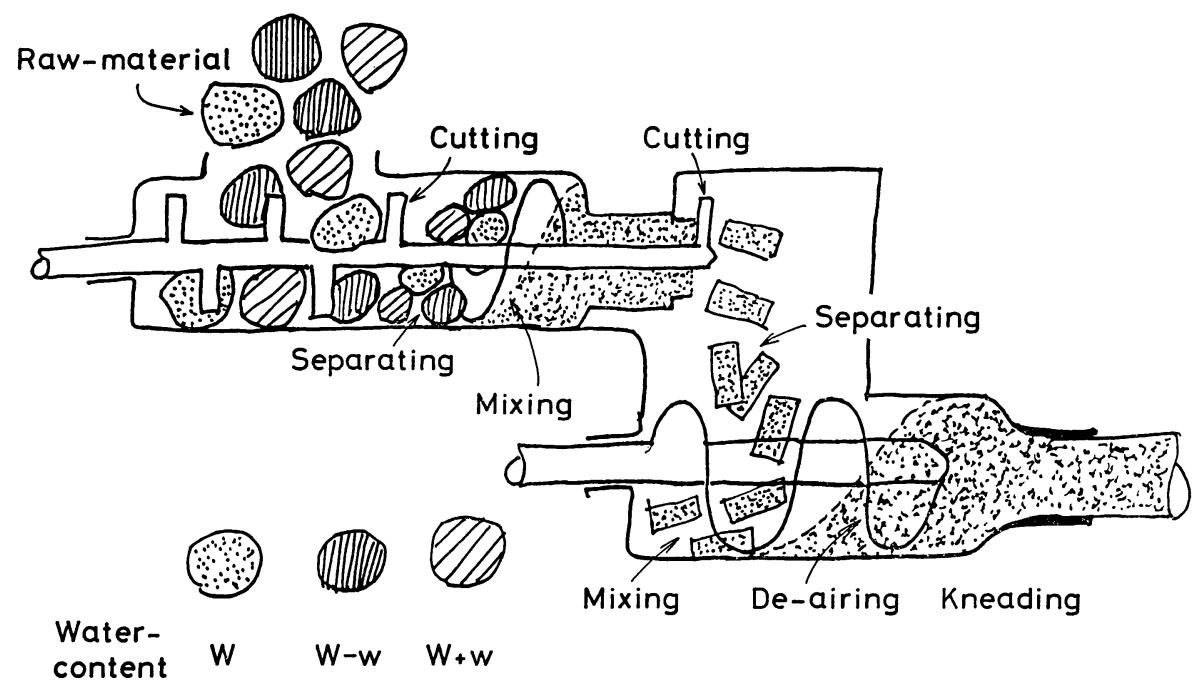

Fig. 31 De-airing kneading machine. 
前段混練部には羽根が設置してあるので，まずこれにより疎原土 は切断され細片化される．これが貯土部に送られ別の羽根により 一体化される (平均水分值に近くなる)。一体化の後では, ダイ ス部を通ってスリットから細紐状体となり排出され, 後カッター により切断され細片となって, 真空室中を落下し後段混練部に入 る.これらの操作は脱気雾囲気中で行なわれるので, 後段混練機 で一体化されるときは，前段混練機中で巻き込まれた空気泡は凡 て排除され，空気を全く含まない泥土に仕上げられ，後段ダイス 部を通り泥土柱として排出される. かくして得られる仕上泥土は Fig. 29 に示した樣に含有水分值に変化は少なく（むしろ真空蒸発 分だけ水分含有量が少なくなっている)，作業性曲線を上位部に 押し上げること（作業性の改善）を果たしているのである。

\section{IV-2. Rankin 圧と Schaxby 圧との関連}

Fig. 32 亿示す様な特殊圧密型を調製し, 次に示すモデル圧密 を実施した。すなわち型中に泥土域（C-1，C-2域）を中心とす る水分含有量を持った配合（I-1-3）を入れ，上部ピストンを下 方に押して型中压密を行ならのである. この時, 上部圧 $P_{\mathrm{axi} \cdot \mathrm{U}}$ と 下部ピストンに伝達される圧力 $P_{\mathrm{axi} \cdot \mathrm{L}}$ 鉝びに側圧 $P_{\mathrm{rad}}$ とを測定 する (Fig. 32 (a)). かくして型中圧密過程を終了した後, 上部 ピストン位置を固定し ((b)図), 今度は側型 (シリンダー) を上 部に引き上げる（このことは, 型中の配合からいえばシリンダー 中を排出 (Exhaust) されることを意味している). かくして排出 過程が終了すると, 最終段階としてシリンダー下部より型中の配 合が“顔”を出す様になり，このことは抜出 (Extrude) 過程に突 入することを意味することになる，故に上記の操作により，压密 過程・抜出過程を通しての $P_{\mathrm{axi} \cdot \mathrm{U}}, P_{\mathrm{axi} \cdot \mathrm{L}}, P_{\mathrm{rad}}$ の変化を追及出 来ることになる.

一つの測定例を Fig. 33 に示して扣いた. 図中 $P_{\mathrm{rad}} / P_{\mathrm{axi} \cdot \mathrm{U}}$ の 值, 同じく $P_{\mathrm{axi} \cdot \mathrm{L}} / P_{\mathrm{axi} \cdot \mathrm{U}}$ の值が示してあるが, 前者は Rankin 压, 後者はSchaxby 圧と呼ばれる, 粉体材料物性を定義する二つ の基礎定数となっているものである.

これによると抜出 (Extrude) 域に入ると Rankin 圧の上升，

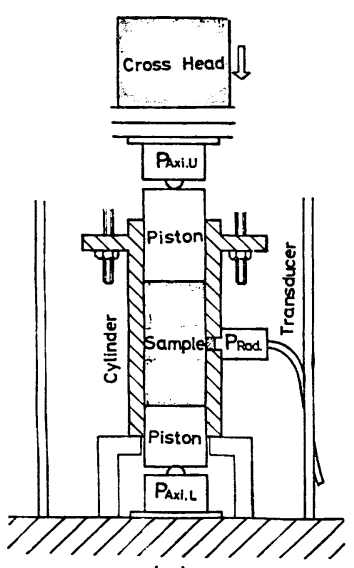

(a)

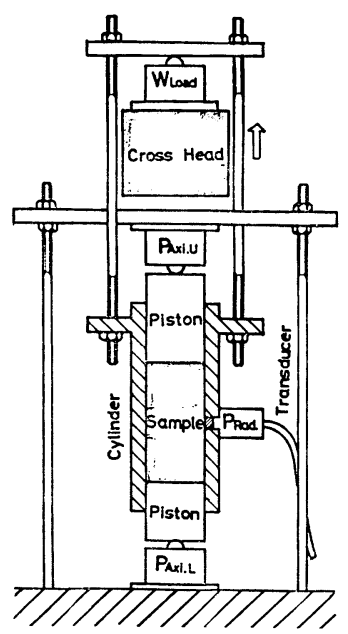

(b)
Fig. 32 Employed apparatus to measure the axial and radial stresses in consolidation, exhausting and extruding procedures.

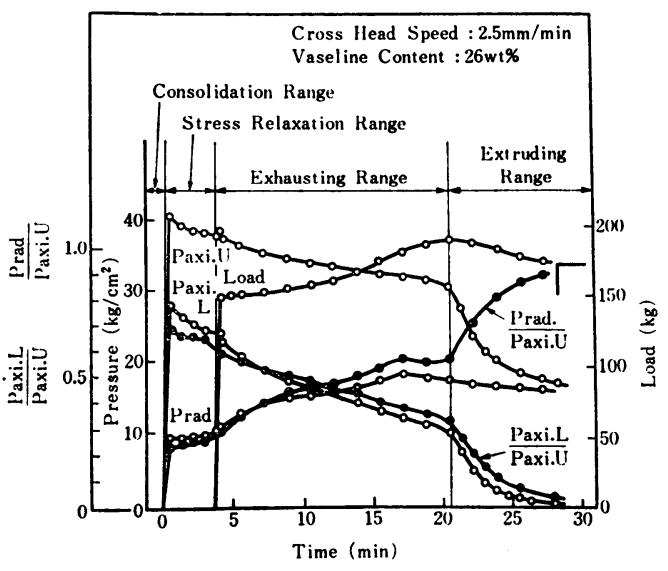

Fig. 33 Measured results for $P_{\mathrm{rad}} / P_{\mathrm{axi} \cdot \mathrm{U}}$ and $P_{\mathrm{axi} \cdot \mathrm{L}} / P_{\mathrm{axi} \cdot \mathrm{v}}$.

並びにSchaxby 圧の下降が顕著になっていることが判明する. 図 に示された関係から抜出成形（排出体を成形体として利用する）, 押出成形（ノズル中に貯土された分を成形体として利用する）の 加工物性を表示する上での重要な指針を得ることが出来るのであ るが，ここでは排出域から抜出域に移る点での Rankin 圧， Schaxby 圧の含有水分依存性にのみ就いて考察する.

Fig. 34 は Rankin 圧, Fig. 35 は Schaxby 圧のかくして得ら れた測定結果であるが，これらの図から Rankin 圧は (Schaxby

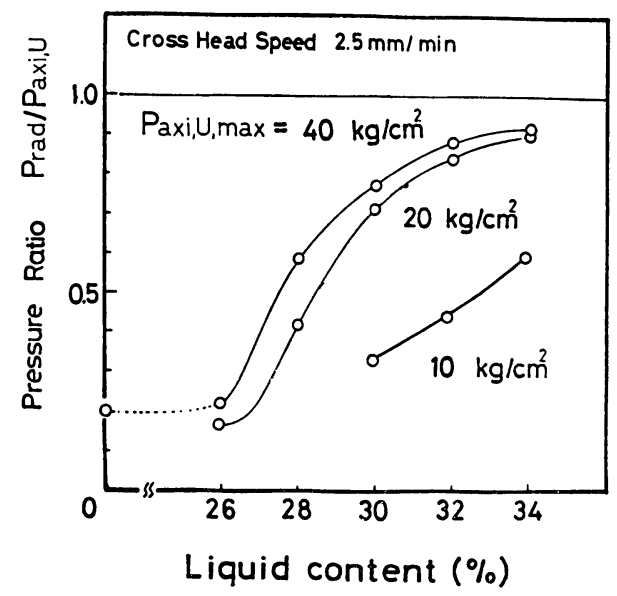

Fig. $34 P_{\mathrm{rad}} / P_{\mathrm{axi} \cdot \mathrm{U}}$ against liquid content.

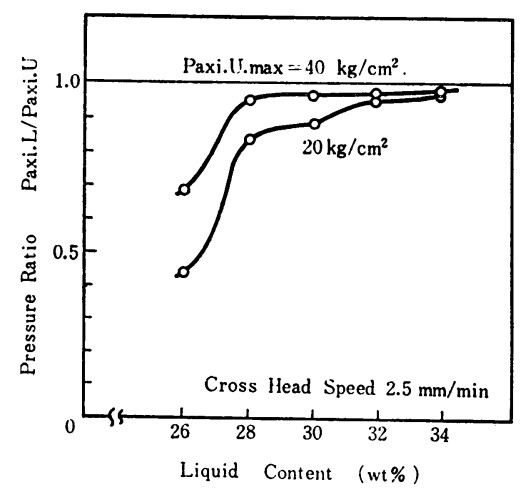

Fig. $35 P_{\mathrm{axi} \cdot \mathrm{L}} / P_{\mathrm{axi} \cdot \mathrm{U}}$ against liquid content. 


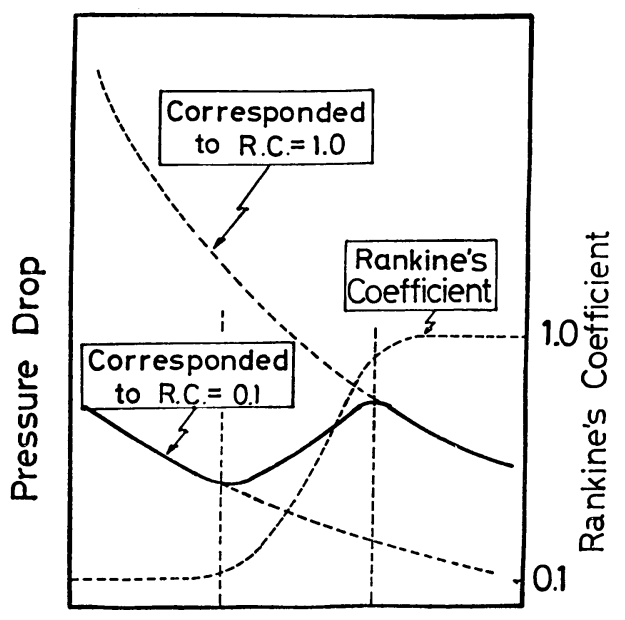

Liquid Content

Fig. 36 Pressure drop and Rankine's coefficient obtained in the mud range of clay powder-liquid system.

压はそれ核ど顕著ではない）粉体領域の小さな值から，泥土領域 に入ると（水分 $26 \%$ の点）上昇傾向が発生し，この傾向は泥漿域 に入る点（水分34\%の点）で飽和しているのを知ることが出来る.

そもとも粘性支配であるということは Rankin 係数が 1.0 亿近 いということであり，又塑性域である粉体域では Rankin 係数が 小である（例えば 0.1）ことは自明のことであるが，泥土域は明 らかに塑性域である值(0.1) から明らかに粘性域である值 (1.0) へと移行している区間であることが示されているということが出 来る.

\section{文献}

全篇に対する参考文献として, 著者の発表した論文・総説・著 書の中の代表例を示しておく. 本来ならその一つ一つに就いて発 表籄所を明示しておくべきであったが，余りに多岐にわたり却っ て繁雑であるので，それに就いては省略した，その代わりに，当 報文の各章節別に仕分けてリストしてあるので, 御必要のうはそ れらを当たって頂きたい，又著者以外の発表者の文献に就いても 出典を明示すべきであるが，これに就いても省略した部分が多い． 著者の原論文からそれを知って頂ければ幸である。

\section{1. 粉体域 (圧縮成形域) での成形理論の体系化並びにその工業 的適用}

1) On the High Pressure Forming of Refractories (I). I. Sawai, K. Umeya, and T. Nishikawa, Bull. Inst. Chem. Res., Kyoto Univ., 32, 94 (1954).

2) On the High Pressure Forming of Refractories (II). I. Sawai, K. Umeya, T. Nishikawa, and K. Yoshida, Bull. Inst. Chem. Res., Kyoto Univ., 32, 94 (1954).

3）粉体成形法と粒子充て九特性との関連性（耐火煉瓦理成形 の場合). 梅屋 薰, 材料試験, 7, 298 (1958).

4）粉体成形関する 2,3 の知見. 梅屋 薰, 案業協会 誌, 68, 145 (1960).

5）粘土製品の成形法と材料特性の関係について. 梅屋 薫,
材料試験，9，696 (1960).

6）粘土質耐火煉瓦素地の熱膨張と粒子充て几構造について. 長崎 钊, 渡辺 明, 吉崎一弘, 梅屋 薰, 敜業協会誌, 96, 323 (1961).

7）素地の熱膨張に基づく空隚容積の非相似的変化について. 長崎 勧, 渡辺 明, 吉崎一弘, 梅屋 薰, 材料試験, 11, 510 (1962).

8）低温に打ける粘土質耐火煉瓦素地の焼成き裂に関する研究. 長崎 勧, 渡辺 明, 吉崎一弘, 梅屋 薰, 材料試験, 11, 568 (1962).

9）ピッチー粉体系のクリープ挙動の温度依存性について。 梅屋 薰, 渡辺 明, 鈴木嘉弘, 材料, 12, 1 (1963).

10）粘土素地の充てん配列の変化に及ぼす収縮性物質の影響. 渡辺 明, 梅屋 董, 材料, 12, 661 (1963).

11）粉粒体の圧縮成形に抢ける充てん構造の変化について. 渡辺 明, 梅屋 薰, 材料, 13，237 (1964).

12）粉粒体の充てん性について。渡辺 明, 梅屋 薰, 材料, 13, 73 (1964).

13）粉体一ピッチ系のクリープ特性について。梅屋 薰, 渡辺 明, 鈴木嘉弘, 材料, 13, 767 (1964).

14）粉体充て几体の収縮時に扮ける挙動に関する模型的観察. 梅屋 薰, 渡辺 明, 中村 孝, 木村稔人, 新田耕司, 材料, 14, 751 (1965).

15）粉体の充てんに関する二，三の知見. 梅屋 薫, 材料, 15, 127 (1966).

16）粉体の内部摩擦について. 梅屋 薰, 北森信之, 荒木征 雄, 美間博之, 材料, 15, 166 (1966).

17）粉粒体の圧縮充てんに及ぼす粒度分布の影響. 渡辺 明, 梅屋 薰, 材料, 15, 172 (1966).

18）プラスチックボール充てん層の densification について. 梅屋 薫, 西川友三, 中島久彰, 窯業協会誌, 75, 301 (1967).

19）粉体の压縮ならびにせん断性について。梅屋 薫, 小松崎 茂樹, 材料, 17，489（1968）。

20）二次元モデルによる粉体の圧縮扔よびせん断機構の研究. 梅屋 薫, 北森信之, 原 隆一, 吉田達郎, 材料, 18, 489 (1969).

21）粉体層の直接せん断に打ける粉体粒子の挙動について. 梅屋 薰, 原 陸一, 吉田達郎, 成広信次, 材料, 19, 521 (1970).

22）二ッケル・亜鉛フェライトのクリープ. 西川友三, 中島 久彰, 石田 徹, 梅屋 薫, 羔業協会誌, 79, 209 (1971).

23）粉体成形体の変形機構. 梅屋 薰, 原 隆一, 吉田達郎, 加藤義德, 材料, 21, 582 (1972).

24）圧縮ならびにせん断時に扣ける粉体のレオロジー的研究. 梅屋 薫, 磯田武信, 原 隆一, 加藤義德, 材料, 22, 637 (1973).

25）湿潤粉体の凝集エネルギーに影響する諸因子。梅屋 薰, 関口 勲, 化学工学, 37, 704 (1973).

26）湿潤粉体のせん断試験における層膨張について。関口 勲, 梅屋 薫, 化学工学, 37, 744 (1973).

27）プラスチックボール充てん体のせん断特性. 梅屋 薰, 
磯田武信, 原 隆一, 菊田潤一, 材料, 23, 549 (1974).

28) On Two-Dimensional Shear Tests by Model Powders.

K. Umeya, R. Hara and J. Kikuta, J. Chem. Eng., Japan, 8, 56 (1975).

29）湿潤粉体の圧密変形特性について. 梅屋 瞢, 関口 勲, 材料, 24, 608 (1975).

30）湿潤粉体の転動凝集機構について。 梅屋 薰, 関口 勲, 材料, 24, 664 (1975).

31）粉体圧縮のレオロジー。 梅屋 薰, 原 隆一, 木村知弘, 材料, 25, 632 (1976).

32）高分子粉体の圧縮成形体のレオロジー的特性. 梅屋 薰, 原 隆一, 井上孝夫, 材料, 27, 618 (1978).

33）加圧成形体の水和による高強度セッコウ硬化体の製造. 加藤義德, 梅屋 薰, 石高亡石灰, No.156, 201 (1978).

34) Some Investigations on the Deformation Character of Piled Bed by Two Dimentional Model. K. Umeya, and R. Hara, Tech. Rep. Tohoku Univ., 43, 111 (1978).

35) Rheological Studies of Compaction for Polymer Powder. K. Umeya, and R. Hara, Polym. Eng. Sci., 18, 366 (1978).

36）加圧成形法による高強度セッコウ硬化体の性質． 加藤義 德, 梅屋 薰, 石膏と石灰, №.164, 21 (1980).

37）セッコウ硬化体の力学特性に拉よぼす界面エネルギーの影 響. 加藤義德, 松井正和, 梅屋 薫, 石膏と石灰, No 166, 83 (1980).

38) On the Rheology of Packed Polymer Powders. K. Umeya and R. Hara, Polymer Eng. Sci., 20, 77 (1980).

39）ポリスチレン粉体圧縮成形体の動的特性. 原 隆一, 鈴木博之, 梅屋 薰, 材料, 29, 887 (1980).

40）高分子粉体の圧縮成形のレオロジー、梅屋 薰, 原 隆一, 高分子論文集，38，231 (1981).

41）ポリスチレン粉体圧縮成形体の三軸圧縮特性. 原 隆一, 梅屋慎次郎，梅屋 薰，材料， 30，78 (1981).

\section{2. 泥しょう域（鋳込成形域）での成形理論の体形化並びにその 工業的適用}

42）泥漿鋳込又に関する二, 三の問題. 梅屋 薰, 材料試験, 4, 195 (1955).

43）鋳込特性の動的測定について。沢井郁太郎, 梅屋 薰, 西川友三, 川本 晋, 材料試験, 4, 447 (1955).

44）泥漿の粘性測定について. 沢井郁太郎, 梅屋 薫, 西川 友三，川本 晋， 材料試験，4，581 (1955).

45）流動鋳込の動的測定. 沢井郁太郎，梅屋 薰, 西川友三, 川本 晋, 清水 聡, 材料試騟, 5, 292 (1955).

46）固形鋳込について. 沢井郁太郎, 梅屋 薫, 西川友三, 川本 晋, 清水 聡, 材料試験, 5, 433 (1956).

47）粘土泥漿に対する電解質の作用. 沢井郁太郎, 西川友三, 清水 聡, 梅屋 薰, 材料試駼, 7, 105 (1958).

48）粘土工業に怙ける泥状物の調製とその作業能について。 梅屋 薰, 工業工学, 25, 382 (1961).

49）粘土懸濁液の摇変性の測定. 梅屋 薰, 材料試験, $\mathbf{1 0}$, 328 (1961).
50）泥漿鋳込成形の流動学的解釈, 梅屋 董, 材料試験, 11, 294 (1962).

51）泥漿，泥状物の流動と変形に扣ける非線型挙動. 梅屋 薰，嚜業協会誌， 71，661（1963）。

52）粉体一水系の䚋拌抵抗， 梅屋 薰，鈴木嘉弘，相島悠二， 化学工業, 28, 682 (1964).

53）二，三の分散体ならびに懸濁体の流動特性について. 梅屋 薫, 磯田武信, 戸枝ふさ子, 石井 忠, 菊地好孝, 城石昭弘, 添田敏之, 材料, 14, 289 (1965).

54）液一液分散体の毛管流動に打ける非線型举動について。 梅屋 薰, 磯田武信, 石井 忠, 材料, 15, 271 (1966).

55) Mixing Torque Characteristics of Powder-Water Systems. K. Umeya, Y. Suzuki, and Y. Aishima, Kagaku Kogaku, 3, 50 (1965).

56）分散体の流動に関する二, 三の考察. 梅屋 薫, 磯田 武信, 石井 忠, 材料, 16, 537 (1967).

57）磁性粉塗料のレオロジー的挙動について。瀬戸順悦, 天谷昭夫, 梅屋 薫, 材料, 16, 537 (1967).

58）酸化チタン䀣濁液の流動挙動について。梅屋 薰, 磯田 武信, 沢村国夫, 材料, 17, 282 (1968).

59) Some Observations on the Flow Properties of Disperse Systems. K. Umeya, T. Isoda, T. Ishii, and K. Sawamura, Powder Tech., 3, 259 (1969).

60）粘土一水懸濁液の流動挙動。梅屋 薫, 磯田武信, 小泉 源三，加藤和男， 材料， 21， 469 (1972).

61）固一液分散系のレオペキシー現象について。梅屋 薫, 菅野隆志, 加藤和男, 庭山 寛, 材料, 22, 406 (1973).

62）固一液分散系の法線応力について。梅屋 薰, 菅野隆志, 豊岡英悦，材料， 22，410 (1973).

63) Flow Properties of Some Suspending Systems. K. Umeya, and S. Tanifuji, Rheol. Acta, 13, 681 (1974).

64）酸化塜鉛一水懸濁液の非ニュートン挙動. 梅屋 薰, 菅野隆志, 加藤和男, 本誌, 2, 7 (1974).

65）ガラスビーズーポリスチレン溶液系の動的粘弾性について。 梅屋 薫, 磯田武信, 大坪泰文, 本誌, 3, 77 (1975).

66）二酸化チタン一水懸濁液のチキソトロピーおよびレオペキ シー的性質. 梅屋 薰, 菅野隆志, 本誌, 3, 102 (1975).

67）高濃度酸化亜鉛一水懸濁液の高せ几断速度域に扣けるダイ ラタント流動. 梅屋 薰, 菅野隆志, 我妻 誠, 本誌, 3, 108 (1975).

68）二酸化チタン一水懸濁液の定常せん断並びに振動的せん断 下に持けるレオロジー的性質. 菅野隆志, 五十嵐秀明, 梅屋 薫, 本誌, 4, 39 (1976).

69）二酸化チタン一水懸濁液のダイラタント流動について. 梅屋 薫, 菅野隆志, 我妻 誠, 本誌, 4, 43 (1976).

70）粉体一高分子溶液系サスペンションのレオロジー的性質. 梅屋 薰, 磯田武信, 大坪泰文, 本誌, 4, 82 (1976).

71) Raised Cosine Pulse を用いた新しい粘弾性測定法. 磯田武信, 大坪泰文, 安紅高秀, 梅屋 薫, 本誌, 4, 133 (1976).

72）ルチル型二酸化チタン一水懸濁液のダイラタント流動. 
菅野隆志, 我妻 誠, 梅屋 薰, 本誌, 4, 170 (1976).

73）粉体一高分子系の非線形粘弾性. 梅屋 薰, 大坪泰文, 色材，49，220 (1976).

74）サスペンションのレオロジー的性質に及ぼす粉体表面の熱 処理の影響. 梅屋 薰, 大坪泰文, 安江高秀, 本誌, 6, 173 (1978).

75）粉体一高分子溶液系サスペンションの大変形下に拈けるレ オロジー的性質. 梅屋 薫, 磯田武信, 大坪泰文, 安江 高秀, 本誌, 6, 79 (1978).

76) Effect of Flocculation on the Dilatant Flow for Aqueous Suspensions of Titanium Dioxides. K. Umeya, and T. Kanno, J. Rheol., 23, 123 (1979).

77）粉体一高分子溶夜系サスペンションの応力緩和. 大坪泰 文, 梅屋 薰, 本誌, 7, 102 (1979).

78) Time-Dependent Behavior of Viscoelastic Suspensions. K. Umeya, and Y. Otsudo, J. Rheol., 24, 239 (1980).

79）焼セッコウ水和のレオロジー. 加藤義德, 梅屋 薰, 石亮と石灰, Na165, 46 (1980).

80）サスペンションのレオロジー的性質に及ぼす粒径の影響. 大坪泰文, 堀米 操, 梅屋 薰, 本誌, 8, 33 (1980).

81）セメントペーストの流動特性. 大坪泰文, 宮井精一, 梅屋 薫, 本誌, 8, 77 (1980).

82）ぬれ状態に扣けるセッコウ硬化体のクリープ特性. 加藤 義德, 梅屋 薰, 石膏と石灰, No.167, 99 (1980).

83) Time-Dependent Flow of Cement Paste. Y. Otsubo, S. Miyai and K. Umeya, Cem. Concr. Res., 10, 631 (1980).

84）懸濁液の擬塑性流動に及ぼす分散剂の影響. 菅野隆志, 梅屋 蓑, 材料, 30,83 (1981).

85）二酸化チタン一水懸濁液のダイラタント流動に及ぼす分散 剂の影響. 菅野隆志, 梅屋 薰, 材料, 30, 303 (1981).

86）セッコウスラリーの㠜結初期に拈けるレオロジー。加藤 義德，松井正和，梅屋 瞢，石膏と石灰， No.170, 13 (1981).

87）セッコウスラリーの流動性扣よび硬化体強度に拈よぼす減 水剤の影響. 加藤義德, 梅屋 薫, 石膏之石灰, Na 171 (1981).

3. 泥土域（ろくろ成形域）での成形理論の体系化並びにそのエ 業的適用

88) On the Bulk Volume of Some Clay-Air-Water Systems. K. Umeya, and I. Sawai, Bull. Inst. Chem. Res., Kyoto Univ., 31, 426 (1953).

89）脱気処理による坏土の可塑性について. 梅屋 薰, 沢井 郁太郎, 材料試験, 2, 34 (1953).

90）坏土中の気泡量について. 梅屋 薰, 沢井郁太郎, 材料 試験， 2, 95 (1953).

91）真空土練機を用いて調整した坏土の乾燥ならびに収縮特性 について, 沢井郁太郎, 梅屋 薰, 西川友三, 材料試験 2, 421 (1953).

92）真空土練圧縮押出機による長尺型二酸化ウラン核燃料の成 形に関する研究. 梅屋 薫, 渡辺 章, 近藤吉明,
日本原子力学会誌， 5, 760 (1973).

93）たばこ粉一水系の流動特性について I. 火力乾燥種たばこ 粉末一水系の押出特性ならびに押出成形体の引張特性につ いて. 清水幸卡, 藤田 哲, 梅屋 薰, 本誌, 5,8 (1977).

94）たばこ粉一水系の流動特性について II. 空気乾燥種たばこ 粉末一水系の応力伝達特性並びに押出特性について. 清水幸夫, 藤田 哲, 梅屋 薫, 本誌, 5, 75 (1977).

95）たばこ粉一水系の流動特性について III.たばこ粉に含有さ れる水溶性成分の見掛け粘性に及洔す影響について。 清水幸夫, 藤田 哲, 梅屋 薫, 本誌, 6, 124 (1978).

96）たばこ粉一水系の流動特性について IV. 応力伝達特性から 見た見掛け粘性に対する水分含量の影響. 藤田 哲, 清水幸夫, 梅屋 薫, 本誌, 7, 102 (1979).

97）非水分散系の押し出しに掓るレオロジー的研究. 菅野 隆志, 小林正人, 梅屋 薑, 材料, 29, 1187 (1980).

\section{4. その他の研究}

98）光学ガラスの化学的耐久性に関する基礎的研究（第 3 報） 水と空気を交互に作用せしめた場合の浸蝕状態に就て. 沢井郁太郎, 田代 仁, 梅屋 薫, 案業協会誌, 52, 198 (1943).

99）光学ガラスの化学的耐久性に関する基礎的研究（第 4 報） 水中に於てガラス表面に生じた珠酸薄膜が亀裂する場合の 活性化エネルギーの算出に就て。沢井郁太郎, 田代 仁, 梅屋 薫, 搳業協会誌, 52, 200 (1943).

100) Studies on the Density of Glass Articles. I. Sawai, M. Tashiro, and K. Umeya, Bull. Inst. Chem. Res. Kyoto Univ., 30, 42 (1952).

101）高分子一粉体系の誘電挙動に関する研究. 梅屋 薰, 瀬戸順悦，材料， 15，365（1966）.

102）シリカゲル，アルミナゲル吸着水の誘電特性について. 梅屋 薰, 菅野隆志, 材料, 17, 285 (1968).

103) Dielectric Rehavior of the Packed Bed of Alumina Granules with Adsorbed Water. K. Umeya, and T. Kanno, Bull. Chem. Soc. Japan, 46, 1660 (1973).

104）動的測定法扔よび Raised Cosine Pulse 法による咯疢の粘 弾性測定. 滝島 任, 志村早苗, 佐藤 茂, 大坪泰文, 梅屋 薰, 医用電子と生体工学, 17, 335 (1979).

105) Relaxation Behavior of Sputum Studied Using the Raised Cosine Pulse Method. S. Shimura, S. Sato, T. Takishima, Y. Otsubo and K. Umeya, Biorheology, 17, 363 (1980).

5. 総 説

106）真空土練について. 沢井郁太郎, 梅屋 薰, 材料試験, 5, 2 (1956).

107）泥しょ5鋳込の流動学的考察. 梅屋 薰, 材料試験, 8, 562 (1959).

108）捏和の機構について. 梅屋 薰, ケミカルエンジニア リング, p. 995 (1959).

109）坏土の捏和について. 梅屋 薰, 岩尾 笱, 化学工学, 24, 230 (1960). 
110）环土の真空捏和について。梅屋 薫, 岩尾 喣, 化学 工学, 24, 343 (1960).

111）摇変性について。梅屋 薫, 材料, 9, 164 (1960).

112） ウラニア原子燃料体の水圧成形について。梅屋 董, 材料試験， 9，546 (1960).

113）濃厚泥しょうの摇変性について。梅屋 憙, 吉崎一弘, 北川達人, 化学工学, 25, 341 (1961).

114）粉体成形論. 梅屋 薰, 化学工業, p. 732 (1961).

115）粉体成形のレオロジー一充てん性からみた理諭一。梅屋 薫, 化学々工業, 14349 (1961).

116）マイクロメリティックスに扔ける充てんの役割. 梅屋 薰, 化学工業, p. 1 (1963).

117）粘土懸濁液の摇変挙動について。梅屋 薰, ケミカル エンジニアリング, p. 1 (1963).

118）捏和抵抗について. 梅屋 瞢, 粉体工学研究会資料, 57号 (1963).

119）泥状物の流動之変形に和ける非線挙動. 梅屋 薰, ケミカルエンジニアリング, p. 1128 (1963).

120）粉体の充媜に関して。梅屋 薰, 粉体工学研究会誌, 2, 205 (1965).

121）粉体成形に损けるレオロジーの役割。梅屋 薰, 化学 と工業，18，250（1965）.

122）粉体のレオロジー（その 1). 梅屋 薰, 化学工業, p. 166 (1966).

123）粉体のレオロジー（その 2). 梅屋 薫, 化学工業, p. 271 (1966)

124）粉体のレオロジー（その 3 ). 梅屋 薰, 化学工業, p. 379 (1966)

125）懸濁・乳濁液の流動特性に関する研究. 梅屋 薫, 磯田 武信, 石井 忠, 旭硝子工業技術奖励会研究郝告, 12, 57 (1966).

126）分散系の粘性について。梅屋 薫, 化学工学, $\mathbf{3 1}$, 1147 (1967).

127）粉体一液体系の力学的挙動一特に泥漿ならびに泥土の機栈 的性質について一， 梅屋 薰, 化学工学, 32, 756 (1968).

128）分散系の粘性（I），梅屋 薰, 高分子, 18，590 (1969).

129）分散系の粘性（II）． 梅屋 薰，高分子， 18，666 (1969).

130) On the Dilatant Behavior of Some Suspensions. K. Umeya, Proc. 4th Int. Cong. Rheol., Vol. 2, p. 295 (1970), ed. by S. Onogi, University of Tokyo Press.

131）チキソトロピー。 梅屋 薰, 磯田武信, 小泉源三, 日本材料学会, 7, 134 (1970).

132）分散系の流動特性に関する研究（第 1 報）。梅屋 薫, 磯田武信， 粉体扣よび粉末ヤ金， 16，329（1970）。

133）分散系の流動特性に関する研究 (第 2 報). 梅屋 薰, 磯田武信， 粉体执よび粉末ヤ金，17，5（1970).

134）分散系の流動特性に関する研究（第 3 報）。梅屋 著, 磯田武信， 粉末抢よび粉末ヤ金， 17，50（1970）。

135）粉体圧縮成形法汇関する研究，梅屋 董，原 隆一，吉田
達郎，旭硝子工業技術奨励会研究報告，17，89（1970）.

136）粉体圧縮成形法に関する研究（第 2 報）三軸圧縮応力下に 括汀る粉体層の変形機構. 梅屋 薫, 原 隆一, 吉田 達郎，加藤義德，旭硝子工業技術奖励会研究報告，19, 183 (1972)

137）分散系の流動曲線. 梅屋 薰. 粉体工学研究会誌, 9, 465 (1972).

138）厚陶管への招待. 梅屋 薫, セラミックス, 8, 945 (1973).

139）粉体材料工学の将来像. 梅屋 薰, 材料, 23, 557 (1974).

140）厚陶管の近代化への試み. 梅屋 薰, セラミックス, 9, 775 (1974).

141） サスペンションのレオロジー． 梅屋 薰. 粉硚, №.19, 80 (1974).

142）懸濁液の硬軟化特性について一チキントロピー,レオペキ シー, 並びにダイラタンシー。梅屋 薰, 菅野隆志, 我妻 誠, 五十嵐秀明, 本誌, 3，145（1975）。

143）粉体材料工学に拈けるレオロジーの役割（その 1)。梅屋 薰, 材料, 24, 103 (1975).

144）粉体材料工学に括けるレオロジーの役割（その 2 ）。梅屋 薰, 材料, 24, 283 (1975).

145) On the Softening and Hardening Flow Properties of Some Suspending Systems (Dynamic Behavior of Thixotropic and Rheopectic Suspending Systems). K. Umeya, and T. Kanno. Proc. 7th Int. Cong. Rheol., p. 180 (1976), ed. by C. Klason and J. Kubat, Sweden Society of Rheology.

146）懸濁系の流動に扮ける硬軟化のレオロジー。梅屋 薫, 本誌， 4, 91 (1976).

147）固体混合物の分離関する基礎的研究. 津屋 升, 竹腰 博文, 荒井賢一，園田 宏，梅屋 薰，東北大学電通談 話会記録，45，122 (1976).

148）粉よりだんご（粉体加工学のすすめ). 梅屋 薫, 材料, 26, 813 (1977).

149）懸濁液のレオロジー（Ｉ）。菅野隆志，梅屋 薫，石育 之石灰, №.146, 47(1977)

150）懸濁液のレオロジー（II）。菅野隆志，梅屋 薰，石高 と石灰, NNo147, 96(1977).

151）懸濁液のレオロジー（III）。菅野隆志, 梅屋 薫, 石高 と石灰, №148, 150(1977).

152）懸濁液のレオロジー（IV). 菅野隆志, 梅屋 薰, 石高 之石灰, №.149, 193(1977).

153）施工理諭からみた耐火物の問題点. 梅屋 薰, 金属, 47, 9 (1977).

154) Rheological Studies of Powder-Liquid Systems. K. Umeya, Proc. U.S.-Japan Seminar on Cotinuum-Mechanical and Statistical Approaches in the Mechanics of Granular Materials, K. Umeya, p. 222 (1978) Gakujutsu Fukyukai.

155）粉体一高分子系材料のレオロジー。梅屋 薫, 大坪泰文, 合成樹脂, 24, 5 (1978).

156）不定形耐火物施工技術の基礎理論, 梅屋 薫, 耐火物, 30, 265 (1978). 
157）変涼うする耐火材料一進む不定形・不焼成化一。梅屋 董, 日本学術振興会協力会報, №.30, 2 (1978).

158），不定形耐火物施工のレオロジー。梅屋 薰, 本誌, 6 , 154 (1978).

159) Rheological Properties of Non-Aqueous Susppensions of Titanium Dioxides Stabilized with Lecithin. K. Umeya and T. Kanno, Proc. 8th Int. Cong. Rheology, in press.

160）新種不定形耐火物の開発研究一不定形耐火物の施工に関す るレオロジー的研究一。梅屋 薰, 菅野隆志, 旭硝子 工業技術奨励会報告, 印刷中.

161）日本がリードするセラミック時代. 梅屋 责, 科学朝日, p. 75 (1980).

\section{6. 著書}

162）捏和. 梅屋 薫, 「化学機械技報11集」, p. 109 (1959) 槙書店.

163）粘土工業におけるレオロジー泥漿の摇変性と鋳込成形一. 梅屋 薰,「化学技術者のためのレオロジー」, p. 174 (1960) 梖書店.

164）捏和（粘土工業に打ける側面），梅屋 薫,「化学機械 技術第14集」，(1961）丸善.

165）レオロジーの諸問題. 梅屋 董, 菅野隆志, 「サスペン ション (固／液分散系) を中心とした分散技術と工学的応 用の実際総合資料集」，p. 139 （1978）経営開発センター 出版部.

166）多孔体の成形. 梅屋 董, 原 隆一, 「多孔材料」, p. 133 (1973) 技報堂.

167）粉体の圧縮ならびに剪断に拈けるレオロジー的挙動. 梅屋 薫, 原 隆一, 「セラミックデータブック79」, p. 70 (1979) 工業製品技術協会.

168）粉体のレオロジー。梅屋 毫，「粉体一理論と応用」 (改訂二版)，p. 354 (1979）丸善.

\section{7. 最近の発表例}

169）粉体一液体系の力学的挙動一特に泥漿ならびに泥土の機栈 的性質について一。 梅屋 薰, 化工, 32, 756 (1968).

170）粉体材料工学に括けるレオロジーの諸問題. 梅屋 薰, 化学工業技術 (1969).

171）粉体成形のレオロジー（充媜性からみた理論）。梅屋 薫, 化学と工業, 14, 349 (1961).

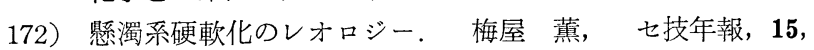
(昭51).

173）湿潤粉体の凝集レオロジーに影響する諸因子． 梅屋 薰, 関口 勲, 化工, 37, 704 (1973).

174） サスペンションのレオロジー的性質に及ぼす粉体表面の熱 処理の影響. 梅屋 薰, 大坪泰文, 安江高秀, 本誌, 6, 173 (1978).

175) On the Softening and Hardening Flow Properties of Some Suspending Systems (Dynamic Behavior of Thixotropic and Rheopectic Systems). K. Umeya, T. Kanno, 7th Int. Cong. on Rheology, Aug. 23 27 (1975), Gothenburg, Sweden,
176) Rheological Studies on Powder-Liquid Systems, K. Umeya, Proc. U.S.-Japan Seminar on Cont.-Mechanical and Stastical Approach in Mech. of Granular Materials, 222 (1978).

177）動的測定法拈よび Raised Cosine Pulse 法による喀疢の粘 弹性測定. 滝島 任, 志村早苗, 佐藤 茂, 大坪泰文, 梅屋 薰, 压電と生化, 17, 7 (昭54).

178) Effect of Flocculation on the Dilatant Flow for Aqueous Suspensions of Titanium Dioxides. K. Umeya, T. Kanno, J. Rheol., 23, 123 (1979).

179）たこば粉一水系の流動特性について IV（応力伝達特性か ら見た見掛けの粘性に刘する水分含量の影響)。藤田 哲, 清水幸夫, 梅屋 薰, 本誌, 7, 102 (1979).

180） セメントモルタルのレオロジー。梅屋 薫, Jap. Cem. Annual. 79, 27 (1979).

181）濃厚固液 2 相系の流動々変形. 梅屋 薰, 非ニュート ン流研究会, 44 (昭55).

182）焼セッコウ水和のレオロジー。加藤義德, 梅屋 薰, 石膏と石灰， 165，46 (1980).

183）加圧成形法による高強度セッコウ硬化体の性質．加藤義德. 梅屋 薰, 石膏と石灰，164，21（1980）.

184）セッコウ硬化体の力学特性に招よぼす界面エネルギーの影 響. 加藤義德, 松井正和, 梅屋 薰, 石膏と石灰, 166, 83 (1980).

185) Frequency Distribution of Visco-Elastic Properties of Sputum Studied by the Raised Cosine Method. T. Okubo, S. Simura, T. Takisima, Y. Otsubo, K. Umeya, 4th Int. Cong. of Biorheology, July 27, 1981, Tokyo.

186）ケイ酸ナトリウム濃厚水溶液のレオロジー的性質，大坪 泰文, 梅屋 薰, 日化, 8, 1201 (1981).

187）エンジニアリング・セラミックスの基礎. 梅屋 薫, 耐火物，8，10 (1981).

188) Aerosil-Separan 溶液系のサスペンションのレオロジー的 性質. 大坪泰文, 梅屋 薰, 本誌, 9, 111 (1981).

189) Effect of Surface Treatment of Particles on the Rheological Properties of Suspensions, Y. Otsubo, M. Horigome, K. Umeya, J. Col. Interface Sci., 83, 240 (1981).

190）セメントペーストのレオロジー特性. 梅屋 薫, 大呯 泰文，コンクリート工学，19，25 (1981).

191）ポリスチレン粉体圧縮成形体の三軸圧縮特性. 原 隆一, 梅屋慎次郎, 梅屋 薰, 材料, 30, 78 (昭56).

192) Rheological Approches to Monolithic Refractories (1), K. Umeya, Taikabutsu Overseas, 2, 49 (1983).

193）膨潤性フッ素雲母一水懸濁液のレオロジー的性質. 大坪 泰文，梅屋 薰，本誌，10，87 (1982).

194) Extensional Viscosities of Silica Dispersion, Y. Otsubo, K. Umeya, J. Appl. Polym. Sci., 27, 1656 (1982).

195）ポリスチレン粉体圧縮成形体の三軸圧縮ならびに三軸伸縮 特性. 原 隆一, 梅屋 薰, 材料, 31, 929（昭57）.

196）セメントペーストに抢ける見挂けの粘度の時間依存性挙動. 梅屋 薫, 任子 明, 下瀬川さ光, 大呯泰文, 材料, 32, 1304 (昭58). 
197）二次元モデルによる粉体層のせん断機構の研究. 原 隆一, 梅屋 瞢, 材料, 32, 492 (昭58).

198）ファインセラミックスの現状（エンジニアリングセラミッ クス成形工学)。梅屋 薰, (1983).
199）エンジニアリングセラミックスに括ける成形工学の展開に ついて. 梅屋 薫, 旭硝子工奖報, 42, 9 (1983).

200）分散系の流動特性. 梅屋 薫, 化工, 46, 18 (1982). 